\title{
Morphological and Physiological Responses in Basil and Brassica Species to Different Proportions of Red, Blue, and Green Wavelengths in Indoor Vertical Farming
}

\author{
Haijie Dou \\ Department of Science \& Technology Development, Beijing Industrial Technology Research Institute, \\ Number 5, Xingguang 4th Avenue, Tongzhou District, Beijing, China 101111; and Department of \\ Horticultural Sciences, Texas A\&M University, College Station, TX 77843 \\ Genhua Niu \\ Texas A\&M AgriLife Research, The Dallas Center, 17360 Coit Road, Dallas, TX 75252 \\ Mengmeng Gu \\ Department of Horticultural Sciences, Texas A\&M AgriLife Extension Service, College Station, TX \\ 77843 \\ Joseph Masabni
Texas A\&M AgriLife Extension Service, The Dallas Center, 17360 Coit Road, Dallas, TX 75252
}

ADDITIONAL INDEX wORDs. biomass production, light quality, photosynthesis, phytochemical accumulation, shade avoidance response

\begin{abstract}
Understanding the responses of plant growth and secondary metabolite synthesis to different light wavelengths is important for optimizing lighting conditions for vegetable production in indoor vertical farms. Basil (Ocimum basilicum) 'Improved Genovese Compact' (green leaf) and 'Red Rubin' (purple leaf), green mustard 'Amara' (Brassica carinata), red mustard 'Red Giant' (Brassica juncea), green kale 'Siberian' (Brassica napus var. pabularia), and red kale 'Scarlet' (Brassica oleracea), which are high-value and multifunctional culinary herbs and leafy greens, were used to characterize the effects of red $(R)$, blue $(B)$, and green $(G)$ wavelengths on plant photosynthesis, morphology, biomass production, and secondary metabolites accumulation. Light quality treatments consisted of three $R$ and $B$ light combinations, $R_{88} B_{12}$ (the proportions of $R$ and $B$ wavelengths were $88 \%$ and $12 \%$, respectively), $R_{76} B_{24}$, and $R_{51} B_{49}$, and two white light combinations, $R_{44} B_{12} G_{44}$ (the proportions of $R$, $B$, and $G$ wavelengths were $44 \%, 12 \%$, and $44 \%$, respectively) and $R_{35} B_{24} G_{41}$. Experiments were conducted in a walk-in growth room with a photosynthetic photon flux density set at $224 \mu \mathrm{mol} \cdot \mathrm{m}^{-2} \cdot \mathrm{s}^{-1}$ and a 16-hour photoperiod. Results indicated that the net photosynthesis in purple basil and green kale were positively correlated with B proportions (BP), and that higher BP increased the relative chlorophyll concentration in purple basil and red kale. In contrast, higher BP suppressed stem elongation and leaf expansion and reduced shoot biomass in all tested species except red mustard. Higher BP increased phytochemical concentrations but decreased the total amounts of phytochemicals per plant. For all basil and brassica (Brassica sp.) cultivars, the inclusion of $G$ wavelengths decreased shoot biomass compared with that of plants grown under $R$ and $B$ light combinations with similar BP. Inclusion of $G$ wavelengths stimulated stem elongation in green basil and green mustard under 12\% BP; whereas it suppressed stem elongation in purple basil, green kale, red kale, and green mustard under $24 \%$ BP. The effects on phytochemical accumulation were species-specific for the inclusion of $G$ wavelengths. Considering biomass production, nutritional values, and working environment for growers, a white light with lower BP and G proportions is recommended for culinary herbs and Brassica leafy greens production at vertical farms.
\end{abstract}

In recent years, food production under controlled environments, especially at vertical farms (VF), has been gaining attention due to the increasing world population, urbanization, global climate change, competition for resources (e.g., land, water, and energy), and increasing demand for locally produced

Received for publication 30 Mar. 2020. Accepted for publication 20 May 2020. Published online 16 June 2020.

This research is supported partially by the U.S. Department of Agriculture National Institute of Food and Agriculture Hatch project TEX090450 and Texas A\&M AgriLife Research. We appreciate the assistance from Dr. Youping Sun, Christina Perez, Triston Hooks, and Zhanyang Xu.

G.N. is the corresponding author. E-mail: gniu@ag.tamu.edu.

This is an open access article distributed under the CC BY-NC-ND license (https://creativecommons.org/licenses/by-nc-nd/4.0/). fresh food with high quality (Despommier, 2013; Kozai et al., 2015; Tornaghi, 2017). Because electricity for powering electrical lighting is one of the largest energy consumption components of $\mathrm{VF}$, optimizing lighting is of great importance. However, lighting conditions significantly affect plant growth, development, and secondary metabolism (Dou et al., 2017, 2018, 2019a, 2019b; Hosseini et al., 2018; Rouphael et al., 2018). With the advancement of light-emitting diode (LED) technology and its customizable nature, the effects of different light wavelengths on plant growth and secondary metabolites accumulation can be characterized (Darko et al., 2014; Mitchell et al., 2015; Ouzounis et al., 2015; Stutte, 2009), thus providing valuable and practical information for the optimization of lighting environments at VF. 
Photosynthetically active radiation $[P A R(400-700 \mathrm{~nm})]$ including blue [B (400-499 nm)], green [G (500-599 nm)], and red [R (600-699 $\mathrm{nm})$ ] wavelengths designates the spectral range providing light energy for photosynthetic organisms, thus affecting the plant biomass accumulation (Kozai et al., 2015). Within the $P A R$ range, $\mathrm{R}$ and $\mathrm{B}$ wavelengths have been studied mainly because of their high absorptivity in the absorption spectra of chlorophyll, with a strong positive correlation between chlorophyll absorption and photosynthetic efficiency (Kopsell et al., 2014; McCree, 1972). In general, a red and blue (R\&B) light combination with a high $\mathrm{R}: \mathrm{B}$ ratio achieves greater plant yield (biomass production) compared with monochromatic R or B wavelengths (Fan et al., 2013; Li, 2010; OhashiKaneko et al., 2007; Wollaeger and Runkle, 2014). However, the optimal $\mathrm{R}: \mathrm{B}$ ratio or $\mathrm{R}$ proportion/B proportion $(\mathrm{RP} / \mathrm{BP})$ in $\mathrm{R} \& \mathrm{~B}$ light combinations for plant growth and biomass accumulation is still unknown and may be crop-specific and cultivar-specific. For instance, Snowden et al. (2016) reported that crop yield was negatively related to or unaffected by BP. Specifically, dry weight (DW) in tomato (Solanum lycopersicum), cucumber (Cucumis sativus), radish (Raphanus sativus), and pepper (Capsicum annum) decreased when BP increased from $11 \%$ to $28 \%$, whereas DW in soybean (Glycine max), lettuce (Lactuca sativa), and wheat (Triticum aestivum) was unaffected by changing BP (Snowden et al., 2016). Similarly, the shoot fresh weight (FW) in lettuce and kale (Brassica oleracea) decreased as BP increased from 0\% to 33\% (Meng et al., 2019). In contrast, shoot FW of basil was highest under $59 \%$ BP compared with plants grown under $48 \%, 40 \%$, and $15 \% \mathrm{BP}$, indicating that crop yield may be positively influenced by BP (Piovene et al., 2015).

It was reported that $\mathrm{R}$ and $\mathrm{B}$ wavelengths influence the biosynthesis of secondary metabolites in plants, particularly phenolics, flavonoids, and anthocyanins. These secondary metabolites have important roles as antioxidants scavenging reactive oxygen species, ultraviolet screening molecules, or anti-infection agents (Klem et al., 2019; Logan et al., 2015). For example, the concentration of rosmarinic acid, the major phenolic acid in basil, was twice that in plants grown under $\mathrm{R}$ and white (W) wavelengths compared with plants grown under $\mathrm{B}$ wavelengths, whereas the concentration of chicoric acid, the second major phenolic acid in basil (Ocimum basilicum), was higher under $\mathrm{B}$ wavelengths than under $\mathrm{R}$ wavelengths (Amaki et al., 2011; Shiga et al., 2009; Shoji et al., 2011). Qian et al. (2016) reported that the maximum content of vitamin $C$ in kale sprouts was detected under $\mathrm{W}$ light, whereas the highest levels of total phenolics and anthocyanins as well as the strongest antioxidant capacity were observed under B wavelengths. Similarly, the 1-menthol content in japanese mint (Mentha arvensis) was enhanced by $\mathrm{R}$ wavelengths, whereas polyphenol, total antioxidants, anthocyanin, and carotenoid concentration in leaf lettuce and $\beta$-carotene and lutein concentrations in spinach (Spinacia oleracea) were increased by B wavelengths (Johkan et al., 2010; Li and Kubota, 2009; Nishioka et al., 2008). Based on previous research, the effects of $R$ and $B$ wavelengths on secondary metabolism vary among plant species and phytochemical compounds, and more research is needed to determine the balance between $\mathrm{R}$ and $\mathrm{B}$ wavelengths to achieve greater yield and higher nutritional quality for plant production in VF.

Compared with $\mathrm{R}$ and $\mathrm{B}$ wavelengths, $\mathrm{G}$ wavelengths are studied less due to their low absorptivity in the absorption spectra of chlorophyll (Kopsell et al., 2014), but the effects of G wavelengths on plant growth are gaining more attention from researchers (Dou et al., 2019a; Folta and Maruhnich, 2007; Terashima et al., 2009; Wang and Folta, 2013; Zhang and Folta, 2012). At the leaf scale or at the whole plant canopy level, the relative quantum efficiency of broadband $\mathrm{G}$ wavelengths is 0.87 , which is slightly lower than that of $\mathrm{R}$ wavelengths $(0.91)$ but higher than that of B wavelengths (0.73) (Sager et al., 1988). Although $\mathrm{R}$ and $\mathrm{B}$ wavelengths are strongly absorbed by the upper plant canopy, $G$ wavelengths penetrate deeper in the plant canopy, which could potentially increase plant photosynthesis in lower plant canopy levels and subsequently increase plant yield at the whole plant canopy level (Dou et al., 2019a; Terashima et al., 2009; Wang and Folta, 2013). In addition, G wavelengths induce shade avoidance responses in plants, such as increased plant height and leaf area, which may increase light interception by a larger plant canopy (Zhang and Folta, 2012). In fact, at a photosynthetic photon flux density (PPFD) of 150 $\mu \mathrm{mol} \cdot \mathrm{m}^{-2} \cdot \mathrm{s}^{-1}$ with a $18-\mathrm{h}$ photoperiod, the leaf area and shoot FW and DW in 'Waldmann's Green' lettuce grown under $\mathrm{R}_{61}$ $\mathrm{B}_{15} \mathrm{G}_{24}[\mathrm{RP}, \mathrm{BP}$, and $\mathrm{G}$ proportion (GP) at $61 \%, 15 \%$, and $24 \%$, respectively] increased by $31 \%, 45 \%$, and $47 \%$, respectively, compared with plants grown under $\mathrm{R}_{84} \mathrm{~B}_{16}$ (Kim et al., 2004). Moreover, the inclusion of $\mathrm{G}$ wavelengths in growth light sources would make plants appear a normal green color instead of purplish, which makes the visual assessment of physiological disorders easier and offers psychological benefits to farm workers. However, other studies reported that $\mathrm{G}$ wavelengths can reverse $\mathrm{B}$ or $\mathrm{R}$ wavelength-induced responses, such as $\mathrm{B}$ wavelength-induced stomatal opening and pigment formation, which negatively affect plant photosynthesis or growth (Folta and Maruhnich, 2007; Talbott et al., 2006). These contrasting results cause the inclusion of $\mathrm{G}$ wavelengths in growth light to be an ongoing discussion.

Basil and Brassica leafy greens are highly diverse in species and cultivars and are a valuable component of the human diet because of their relatively high levels of bioactive secondary metabolites (Keservani et al., 2010; Makri and Kintzios, 2008; Qian et al., 2016). There have been many studies focused on the effects of $\mathrm{R}$ and $\mathrm{B}$ wavelengths or the effects of $\mathrm{G}$ wavelengths on plant growth, but extensive research regarding plant responses to changing RP, BP, and GP together is still required, especially for different plant species and cultivars. Based on previous research, we chose three $R \& B$ light combinations with higher R:B ratios and two $\mathrm{W}$ light (inclusion of $\mathrm{G}$ wavelengths to $R \& B$ wavelengths) to investigate the effects of different RP, $\mathrm{BP}$, and GP on photosynthesis, morphology, yield, and secondary metabolism in basil and Brassica species (model plants) in VF. Specifically, we aimed to: 1) determine the optimal R:B ratio for green and purple/red leaf basil and Brassica leafy greens production; and 2) characterize if inclusion of $\mathrm{G}$ wavelengths will increase plant biomass production and alter plant secondary metabolism. These study findings should provide a theoretical basis for the definition of optimal light quality for high yield and improved nutritional quality production of culinary herbs and Brassica leafy greens cultivated at VF.

\section{Materials and Methods}

\section{Plant materials and growing conditions}

All experiments were conducted in a walk-in growth room $\left(35 \mathrm{~m}^{2}\right)$ with vertical grow racks at Texas A\&M AgriLife 
Research Center in El Paso using basil (green leaf 'Improved Genovese Compact' and purple leaf 'Red Rubin'), mustard [green leaf 'Amara' (Brassica carinata) and red leaf 'Red Giant' (Brassica juncea)], and kale [green leaf 'Siberian' (Brassica napus var. pabularia) and red leaf 'Scarlet' (B. oleracea)] (Johnny's Selected Seeds, Winslow, ME). Experiments for multiple species were conducted during separate time periods, and the treatment time was different for each cultivar due to different growth rate. The experiments for green and purple basil were conducted twice per cultivar, and experiments for mustard and kale were conducted one time per cultivar. Green and purple basil were harvested at 21 and $28 \mathrm{~d}$ after treatment (DAT), respectively, which were at 42 and $49 \mathrm{~d}$ after sowing (DAS), respectively. Green and red mustard were both harvested at 21 DAT (35 DAS). Green and red kale were harvested at 18 and 25 DAT (32 and 39 DAS), respectively. All plants were harvested when the plant height reached $\approx 25 \mathrm{~cm}$.

For all experiments, one seed per cell was sown in 72square-cell trays (cell size, $3.86 \mathrm{~cm}$ length $\times 5.72 \mathrm{~cm}$ height; volume, $59 \mathrm{~cm}^{3}$ ) with substrate (peatmoss $41 \%$, vermiculite $34 \%$, pine bark 25\%; Metro-Mix 360; Sun Gro Horticulture, Bellevue, WA). All trays were placed under intermittent mist (15 s every $30 \mathrm{~min}$ ) in a polycarbonate greenhouse for germination. Seedlings were moved from the mist after emergence of cotyledon and grown in a greenhouse until transplanting. The average temperatures and relative humidity in the greenhouse for green leaf basil, purple leaf basil, mustard, and kale were as follows: $28.2 \pm 2.8 / 18.1 \pm 3.9^{\circ} \mathrm{C}$ and $28 \% \pm 6 \%$ / $38 \% \pm 7 \% ; 24.0 \pm 3.6 / 16.3 \pm 3.2{ }^{\circ} \mathrm{C}$ and $34 \% \pm 10 \% / 52 \% \pm$ $10 \% ; 25.9 \pm 3.0 / 19.4 \pm 1.3{ }^{\circ} \mathrm{C}$ and $18 \% \pm 5 \% / 36 \% \pm 7 \%$; and $25.6 \pm 3.0 / 19.8 \pm 1.6{ }^{\circ} \mathrm{C}$ and $20 \% \pm 8 \% / 33 \% \pm 6 \%$ (day/night), respectively. For each cultivar, 150 seedlings with one pair of true leaves expanded were transplanted to grow pots (pot size, $9.52 \mathrm{~cm}$ length $\times 8.26 \mathrm{~cm}$ height; volume, $\left.574 \mathrm{~cm}^{3}\right)$ with substrate. Uniform plants were selected and moved to the walkin growth room to initiate the different light quality treatments. There were 18,12 , and 12 plants per treatment per cultivar for basil, kale, and mustard, respectively. For five light quality treatment, two vertical grow racks with four shelves per grow rack were used, and each shelf was designated as one light treatment.

After transplanting, all plants were sub-irrigated manually with a nutrient solution containing $1.88 \mathrm{~g} \cdot \mathrm{L}^{-1} 15 \mathrm{~N}-2.2 \mathrm{P}-12.5 \mathrm{~K}$ water-soluble fertilizer (Peters 15-5-15 Ca-Mg Special; Scotts Co., Marysville, $\mathrm{OH}$ ) as needed. The nutrient solution was mixed and stored in a 378-L tank with lid, and the electrical conductivity (EC) was $2.01 \pm 0.06 \mathrm{dS} \cdot \mathrm{m}^{-1}$ throughout the experiment, which was measured using an EC/pH meter (model B-173; Horiba, Kyoto, Japan). The $\mathrm{pH}$ of the nutrient solution was measured using the aforementioned $\mathrm{EC} / \mathrm{pH}$ meter and adjusted to $5.98 \pm 0.03$ using potassium hydroxide. Planting density for all cultivars was 79 plants $/ \mathrm{m}^{2}$. The air temperature in the growth room was set at $24 / 21{ }^{\circ} \mathrm{C}$ (day/night) for basil, mustard, and kale. The relative humidity and $\mathrm{CO}_{2}$ concentration were not controlled in the growth room. The plant canopy temperature of each treatment was recorded every 30 min using type- $\mathrm{T}$ thermocouples connected to a datalogger (CR1000; Campbell Scientific, Logan, UT). The average plant canopy temperatures during the experiment were $23.5 \pm 0.25 / 21.3 \pm$ $0.20,23.4 \pm 0.31 / 20.2 \pm 0.17$, and $22.5 \pm 0.23 / 20.0 \pm 0.20{ }^{\circ} \mathrm{C}$ (day/night) for basil, mustard, and kale, respectively. Mechanical mini fans (LS1225A-X; AC Infinity, City of Industry, CA) were used for air circulation to achieve uniform temperatures across treatments.

\section{Light quality treatments}

A total of five light quality treatments were used: three $R \& B$ LED light combinations with different $\mathrm{BP}$ and two $\mathrm{W}$ light (inclusion of $\mathrm{G}$ wavelengths). The three $\mathrm{R} \& \mathrm{~B}$ light combinations consisted of $\mathrm{R}_{88} \mathrm{~B}_{12}$ (model GEHL48HPPR; GE Current, Boston, MA), $\mathrm{R}_{76} \mathrm{~B}_{24}$ (model GEHL48HPPB; GE Current), and $\mathrm{R}_{51} \mathrm{~B}_{49}$ (model GEHL48HPPV; GE Current). The two W light treatments consisted of $\mathrm{R}_{44} \mathrm{~B}_{12} \mathrm{G}_{44}$ (W LED; model GEHL48HWTB; GE Current) and $\mathrm{R}_{35} \mathrm{~B}_{24} \mathrm{G}_{41}$ (W fluorescent light; cool White Alto Linear; Philips Lighting, Somerset, NJ). All treatments were maintained at the same PPFD level of 224 $\pm 12 \mu \mathrm{mol} \cdot \mathrm{m}^{-2} \cdot \mathrm{s}^{-1}$ with a 16 -h photoperiod from 0600 to 2200 HR. Light spectral distribution (Fig. 1) and PPFD were measured at $15 \mathrm{~cm}$ underneath the light source at nine spots for each treatment using a PS-100 spectroradiometer (Apogee Instruments, Logan, UT) before placing plants. To minimize disproportionate light distribution within each treatment, all plants were rearranged systematically every $3 \mathrm{~d}$.

\section{Measurements}

Gas EXChange RATE AND RELATIVE CHLOROPHYLl CONTENT. A portable gas exchange analyzer (CIRAS-3; PP Systems, Amesbury, MA) was used to measure the comparative net photosynthesis $\left(\mathrm{P}_{\mathrm{n}}\right)$ of plant leaves at harvest. A leaf cuvette (PLC3; PP Systems) with an LED light unit (W light, in which $\mathrm{RP}, \mathrm{BP}$, and GP were $38 \%, 25 \%$, and $37 \%$, respectively) was used, and $P P F D$, relative air humidity, and $\mathrm{CO}_{2}$ concentration inside the leaf chamber were kept constant at $800 \mu \mathrm{mol} \cdot \mathrm{m}^{-2} \cdot \mathrm{s}^{-1}$, $50 \%$, and $390 \mu \mathrm{mol} \cdot \mathrm{mol}^{-1}$, respectively. The third leaf from the top (the uppermost fully expanded leaf) was used for measurements. Measurements were obtained when $P_{n}$ reached a steady state.

The soil plant analysis development (SPAD) index of basil leaves was measured at harvest to quantify relative chlorophyll content using a chlorophyll meter (SPAD-502; KonicaMinolta, Osaka, Japan). The third leaf from the top was used for

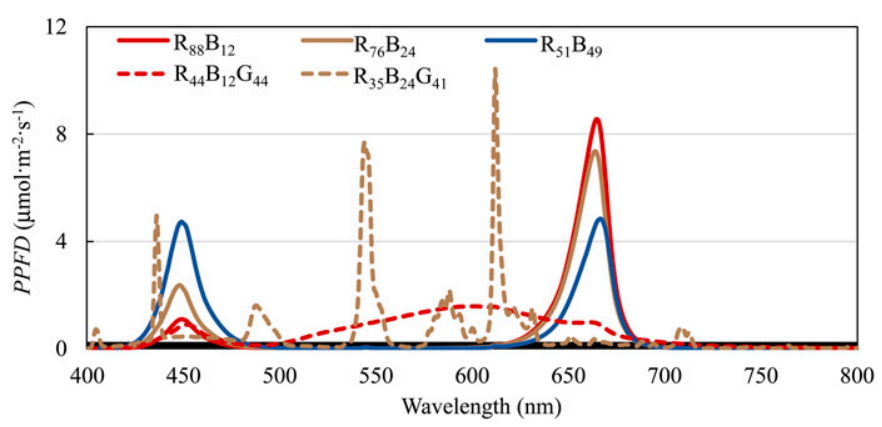

Fig. 1. Spectral distribution of different light quality treatments including three combined red (R) and blue (B) light combinations, $\mathrm{R}_{88} \mathrm{~B}_{12}$ (the proportions of $\mathrm{R}$ and $\mathrm{B}$ wavelengths were $88 \%$ and $12 \%$, respectively), $\mathrm{R}_{76} \mathrm{~B}_{24}$ (the proportions of $R$ and $B$ wavelengths were $76 \%$ and $24 \%$, respectively), and $\mathrm{R}_{51} \mathrm{~B}_{49}$ (the proportions of $\mathrm{R}$ and $\mathrm{B}$ wavelengths were $51 \%$ and $49 \%$, respectively), and two white light combinations, $\mathrm{R}_{44} \mathrm{~B}_{12} \mathrm{G}_{44}$ [white lightemitting diode with $\mathrm{R}, \mathrm{B}$, and green $(\mathrm{G})$ wavelength proportions of $44 \%, 12 \%$, and $44 \%$, respectively] and $\mathrm{R}_{35} \mathrm{~B}_{24} \mathrm{G}_{41}$ (white fluorescent light with $\mathrm{R}, \mathrm{B}$, and $\mathrm{G}$ wavelength proportions of $35 \%, 24 \%$, and $41 \%$, respectively). Photosynthetic photon flux density (PPFD) and spectral distribution were measured using a spectroradiometer (PS-100; Apogee Instruments, Logan, UT). 
measurements. Three measurements were obtained for each plant and the average was recorded for data analysis.

Growth PARAMETERS AND YIELD. Growth characteristics including plant height and leaf area were recorded at harvest. Plant yield including shoot FW and DW were also measured at the end of the experiment. Leaf area was measured using a leaf area meter (LI-3100; LI-COR, Lincoln, NE). Shoot tissues were dried at $80^{\circ} \mathrm{C}$ in a drying oven (Grieve, Round Lake, IL) for $3 \mathrm{~d}$ to determine the shoot DW. The specific leaf area (SLA) was calculated as the ratio of the leaf area to the leaf DW.

Secondary Plant metabolites. Extraction. Fresh leaves were collected in a cooler and immediately stored in a deep freezer (IU1786A; Thermo Fisher Scientific, Waltham, MA) at $-80{ }^{\circ} \mathrm{C}$ until phytochemical analyses. Approximately $2 \mathrm{~g}$ of fresh leaves were ground in liquid nitrogen and extracted with $15 \mathrm{~mL}$ $1 \%$ acidified methanol in darkness. After overnight extraction, the mixture was centrifuged (Sorvall RC 6 Plus; Thermo Fisher Scientific) at $26,669 g_{\mathrm{n}}$ for $15 \mathrm{~min}$, and the supernatant was collected for phytochemical analyses (Xu and Mou, 2016).

Anthocyanin analysis. Absorbance of the extract collected from extraction was measured at $530 \mathrm{~nm}$ vs. acidified methanol (1\%) blank using a spectrophotometer (Genesys 10S ultraviolet/Vis; Thermo Fisher Scientific). Because the extracts were prepared from leaf tissues maintained at $-80{ }^{\circ} \mathrm{C}$ and did not undergo extensive processing or significant browning, a $\mathrm{pH}$ differential method for anthocyanin content was considered unnecessary (Connor et al., 2002). Anthocyanin concentration was expressed as milligrams of cyanidin-3-glucoside equivalent per $100 \mathrm{~g} \mathrm{FW}$ of plant leaves using a molar extinction coefficient of 29,600, which was calculated as follows (Connor et al., 2002):

$$
\begin{aligned}
& \text { Anthocyanin concentration }(\mathrm{mg} / 100 \mathrm{~g} \mathrm{FW}) \\
& =\frac{V \times n \times M \times A \times 100}{\varepsilon \times m}
\end{aligned}
$$

where $V$ is the volume of extracted liquid (milliliters), $n$ is the dilution factor, $\mathrm{M}$ is the molecular weight of cyaniding-3glucoside (449.2), $A$ is the absorbance at $530 \mathrm{~nm}, \varepsilon$ is the molar extinction coefficient $(29,600)$, and $m$ is the weight of the sample.

Phenolics analysis. The total phenolics concentration of plant leaves was determined using the modified Folin-Ciocalteu reagent method (Xu and $\mathrm{Mou}, 2016)$ as follows: $100-\mu \mathrm{L}$ extraction sample was added to a mixture of $150 \mu \mathrm{L}$ distilled water and $750 \mu \mathrm{L} \mathrm{10 \%}$ dilution Folin-Ciocalteu reagent. After a 6-min reaction, $600 \mu \mathrm{L} 7.5 \% \mathrm{Na}_{2} \mathrm{CO}_{3}$ was added and the mixture was incubated at $45^{\circ} \mathrm{C}$ in a water bath for $10 \mathrm{~min}$ before the absorbance was measured at $725 \mathrm{~nm}$ using a microplate reader (ELx800; BioTek, Winooski, VT). Results were expressed as milligrams of gallic acid equivalent per gram FW of plant leaves.

Flavonoids analysis. The total flavonoid concentration of plant leaves was determined (Dou et al., 2018) as follows: 20$\mu \mathrm{L}$ extraction sample was added to a mixture of $85 \mu \mathrm{L}$ distilled water and $5 \mu \mathrm{L} 5 \% \mathrm{NaNO}_{2}$. After a 6 -min reaction, $10 \mu \mathrm{L}$ of $10 \% \mathrm{AlCl}_{3} \cdot 6 \mathrm{H}_{2} \mathrm{O}$ was added to the mixture. After another 5min reaction, $35 \mu \mathrm{L}$ of $1 \mathrm{M} \mathrm{NaOH}$ and $20 \mu \mathrm{L}$ distilled water were added to the mixture and absorbance was measured at 520 $\mathrm{nm}$ using the aforementioned microplate reader. Results were expressed as milligrams $(+)$-catechin hydrate equivalent per gram FW of plant leaves.
Antioxidant capacity analysis. The antioxidant capacity of plant leaves was measured using the 2,2'-azino-bis(3-ethylbenzothiazoline-6-sulphonic acid) (ABTS) method (Arnao et al., 2001) as follows: a mixture of $150 \mu \mathrm{L}$ of basil leave extract was added to $2.85 \mathrm{~mL}$ of colored free radical ABTS $\left(\mathrm{ABTS}^{+}\right)$solution and incubated at room temperature for 10 min. Absorbance of the mixture was measured at $734 \mathrm{~nm}$ using the aforementioned spectrophotometer. The antioxidant capacity was expressed as milligrams of Trolox equivalent antioxidant capacity per $100 \mathrm{~g} \mathrm{FW}$ of plant leaves.

\section{Statistical analysis}

The experiment was designed as a completely randomized design to test the effects of light quality (changing RP, BP, and GP) on all measured parameters. Five plants per cultivar per treatment were selected for each measurement. One-way analysis of variance was conducted and a mean comparison among treatments was conducted using Tukey's honestly significant difference test $(P \leq 0.05)$. A correlation test was conducted using a pairwise correlations method, and the correlation coefficient $\gamma$ is presented when a correlation is significant $(P$ $\leq 0.05)$. All statistical analyses were performed using JMP software (version 13; SAS Institute, Cary, NC).

\section{Results}

\section{Morphological and physiological responses in basil to different RP, BP, and GP}

Light quality showed no effects on comparative $\mathrm{P}_{n}$ or SPAD of green basil (Figs. 2 and 3). In purple basil, comparative $P_{n}$ under $\mathrm{R}_{51} \mathrm{~B}_{49}$ was $15 \%$ to $34 \%$ higher compared with plants grown under other treatments (Fig. 2) and was positively correlated with BP with a coefficient of 0.9107 . Similarly, the SPAD reading of purple basil was highest under $R_{51} B_{49}$ and $R_{76}$ $B_{24}$ (Fig. 3). The inclusion of $G$ wavelengths showed no effect on comparative $\mathrm{P}_{\mathrm{n}}$ in purple basil compared with plants grown under R\&B light combinations with similar BP (Fig. 2).

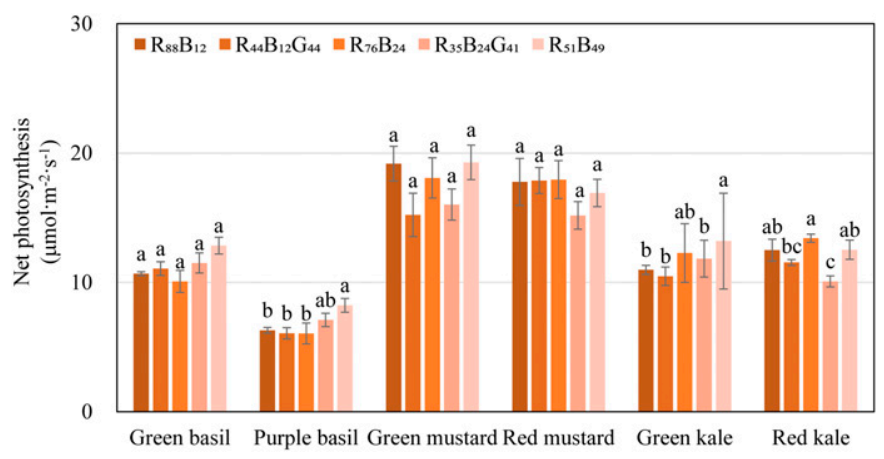

Fig. 2. Net photosynthesis of green basil 'Improved Genovese Compact', purple basil 'Red Rubin', green mustard 'Amara', red mustard 'Red Giant', green kale 'Siberian', and red kale 'Scarlet' grown under five light quality treatments: three combined red (R) and blue (B) light combinations, $\mathrm{R}_{88} \mathrm{~B}_{12}$ (the proportions of $\mathrm{R}$ and $\mathrm{B}$ wavelengths were $88 \%$ and $12 \%$, respectively), $\mathrm{R}_{76} \mathrm{~B}_{24}$ (the proportions of $\mathrm{R}$ and $\mathrm{B}$ wavelength were $76 \%$ and $24 \%$, respectively), and $\mathrm{R}_{51} \mathrm{~B}_{49}$ (the proportions of $\mathrm{R}$ and $\mathrm{B}$ wavelengths were $51 \%$ and $49 \%$, respectively) and two white light combinations, $\mathrm{R}_{44} \mathrm{~B}_{12} \mathrm{G}_{44}$ [white light-emitting diode with R, B, and green $(\mathrm{G})$ wavelength proportions of $44 \%, 12 \%$, and $44 \%$, respectively] and $\mathrm{R}_{35} \mathrm{~B}_{24} \mathrm{G}_{41}$ (white fluorescent light with $\mathrm{R}, \mathrm{B}$, and $\mathrm{G}$ wavelength proportions of $35 \%, 24 \%$, and $41 \%$, respectively). Means followed by different lowercase letters indicate a significant difference according to one-way analysis of variance $(P \leq 0.05)$. 


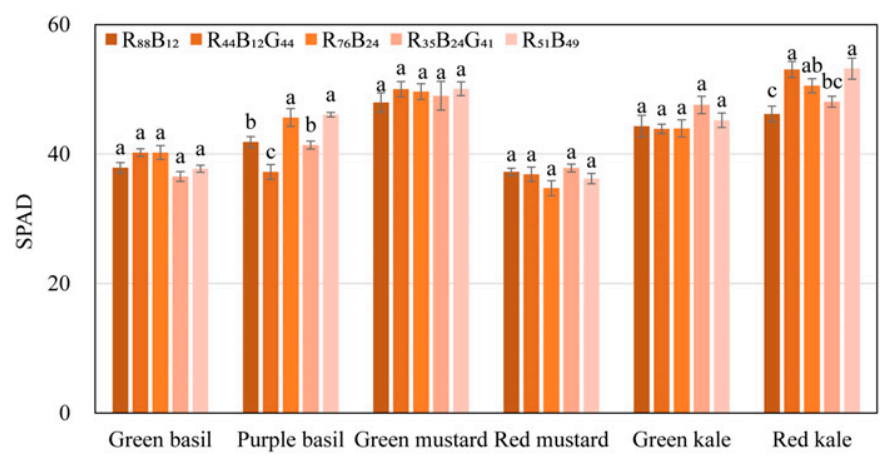

Fig. 3. Soil plant analysis development (SPAD) measurements of green basil 'Improved Genovese Compact', purple basil 'Red Rubin', green mustard 'Amara', red mustard 'Red Giant', green kale 'Siberian', and red kale 'Scarlet' grown under three combined red (R) and blue (B) light combinations, $\mathrm{R}_{88} \mathrm{~B}_{12}$ (the proportions of $\mathrm{R}$ and $\mathrm{B}$ wavelengths were $88 \%$ and $12 \%$, respectively), $\mathrm{R}_{76} \mathrm{~B}_{24}$ (the proportions of $\mathrm{R}$ and $\mathrm{B}$ wavelengths were $76 \%$ and $24 \%$, respectively), and $\mathrm{R}_{51} \mathrm{~B}_{49}$ (the proportions of $\mathrm{R}$ and $\mathrm{B}$ wavelengths were $51 \%$ and $49 \%$, respectively), and two white light combinations, $\mathrm{R}_{44} \mathrm{~B}_{12} \mathrm{G}_{44}$ [white light-emitting diode with $\mathrm{R}, \mathrm{B}$, and green $(\mathrm{G})$ wavelength proportions of $44 \%, 12 \%$, and $44 \%$, respectively] and $\mathrm{R}_{35} \mathrm{~B}_{24} \mathrm{G}_{41}$ (white fluorescent light with $\mathrm{R}, \mathrm{B}$, and $\mathrm{G}$ wavelength proportions of $35 \%, 24 \%$, and $41 \%$, respectively). Means followed by different lowercase letters indicate a significant difference according to one-way analysis of variance $(P \leq 0.05)$.

However, the inclusion of $\mathrm{G}$ wavelengths decreased SPAD in purple basil by $11 \%$ and $9 \%$ compared with plants grown under R\&B light combinations with $12 \%$ and $24 \%$ BP, respectively (Fig. 3).

The plant height and leaf area of green basil were both lowest under treatments $\mathrm{R}_{51} \mathrm{~B}_{49}$ and $\mathrm{R}_{76} \mathrm{~B}_{24}$ among the three $\mathrm{R} \& \mathrm{~B}$ light combinations (Fig. 4A). The plant height and leaf area of purple basil were both lowest under treatment $\mathrm{R}_{51} \mathrm{~B}_{49}$ among the three R\&B light combinations (Fig. 4B). Under 12\% BP, the inclusion of $\mathrm{G}$ wavelengths increased the plant height of green basil, but it showed no effects on purple basil. In contrast, under $24 \%$ BP, the inclusion of $\mathrm{G}$ wavelengths showed no effects on plant height of green basil, but it decreased the plant height of purple basil (Fig. $4 \mathrm{~A}$ and $\mathrm{B}$ ). The leaf area of green basil tended to decrease by the inclusion of $\mathrm{G}$ wavelengths, but the difference was not significant. The leaf area of purple basil was $26 \%$ to $44 \%$ lower with the inclusion of $\mathrm{G}$ wavelengths. Light quality treatments showed no effects on the SLA of basil, regardless of cultivar. No correlations between plant height and $\mathrm{BP}, \mathrm{RP}$, or $\mathrm{R}: \mathrm{B}$ ratios were observed in green or purple basil. The leaf area of green basil was positively correlated with $\mathrm{R}: \mathrm{B}$ ratios, with a coefficient of 0.9854 , whereas the leaf area of purple basil was positively correlated with RP, with a coefficient of 0.9504 .

The shoot FW and DW of green basil were both positively correlated with R:B ratios, with coefficients of 0.9929 and 0.9518 , respectively. The shoot FW and DW of purple basil were both positively correlated with RP, with coefficients of 0.9587 and 0.8977 , respectively. No correlations were observed between plant yield with BP. Among the three R\&B light combinations, shoot FW and DW of green basil were both lowest under treatments $\mathrm{R}_{51} \mathrm{~B}_{49}$ and $\mathrm{R}_{76} \mathrm{~B}_{24}$; however, for purple basil, they were both lowest under $\mathrm{R}_{51} \mathrm{~B}_{49}$ (Fig. 5A and $\mathrm{B}$ ). The inclusion of $\mathrm{G}$ wavelengths decreased shoot $\mathrm{FW}$ and DW of purple basil by $28 \%$ to $35 \%$ and $27 \%$ to $41 \%$, respectively, compared with $\mathrm{R} \& \mathrm{~B}$ light combinations with similar BP, whereas it decreased the shoot $\mathrm{FW}$ of green basil by $15 \%$ under $12 \%$ BP (Fig. $5 \mathrm{~A}$ and $\mathrm{B}$ ).
Different light quality treatments showed no effects on the anthocyanin concentration of green or purple basils (Table 1). Among the three R\&B light combinations, the flavonoids concentration in and antioxidant capacity of green basil were both highest under $\mathrm{R}_{76} \mathrm{~B}_{24}$ and decreased under $12 \%$ or $49 \%$ $\mathrm{BP}$, whereas the phenolics concentration was unaffected by BP. Among the three R\&B light combinations, the phenolics concentration in purple basil increased with increasing BP, whereas the flavonoids concentration in and antioxidant capacity were highest under $\mathrm{R}_{76} \mathrm{~B}_{24}$ and $\mathrm{R}_{51} \mathrm{~B}_{49}$ and lowest under $\mathrm{R}_{88}$ $\mathrm{B}_{12}$ (Table 1). Under $12 \% \mathrm{BP}$, the phenolics concentration in green basil decreased with the inclusion of $\mathrm{G}$ wavelengths, whereas the flavonoids concentration in and antioxidant capacity were unaffected. In contrast, under $12 \% \mathrm{BP}$, the phenolics concentration in purple basil was unaffected by the inclusion of $\mathrm{G}$ wavelengths, whereas the flavonoids concentration in and antioxidant capacity decreased. Under $24 \%$ BP, the phenolics concentration and flavonoids concentration in and antioxidant capacity of green and purple basils all decreased with the inclusion of $\mathrm{G}$ wavelengths. No correlations between phytochemical parameters and BP, RP, or R:B ratios were observed in green or purple basil.

The total amounts of anthocyanin, phenolics, and flavonoids in and antioxidant capacity per plant were calculated by multiplying the concentrations of each parameter with leaf FW per plant. Among the three R\&B light combinations, the total amounts of anthocyanin in both cultivars were highest under $\mathrm{R}_{88} \mathrm{~B}_{12}$ and $\mathrm{R}_{76} \mathrm{~B}_{24}$ and the same as the total amounts of phenolics in green basil, whereas the total amount of flavonoids in and antioxidant capacity in both cultivars and the total amount of phenolics in purple basil were all highest under $\mathrm{R}_{76}$ $\mathrm{B}_{24}$ (Table 2). The total amount of anthocyanin in green basil under both BP and the total amount of flavonoids in green basil under $12 \%$ BP were unaffected by inclusion of $\mathrm{G}$ wavelengths, whereas other total amounts of phytochemicals per plant (i.e., anthocyanin, phenolics, flavonoids, and antioxidant capacity) decreased with inclusion of $\mathrm{G}$ wavelengths, regardless of $\mathrm{BP}$ (Table 2).

\section{Morphological and physiological responses in mustard to different RP, BP, and GP}

Among the different light quality treatments, no difference was observed in the $\mathrm{P}_{\mathrm{n}}$ or SPAD of green mustard and red mustard (Figs. 2 and 3 ).

The plant height and leaf area of green mustard were both negatively correlated with BP, with coefficients of -0.8958 and -0.8844 , respectively, whereas the leaf area of green mustard was positively correlated with $\mathrm{R}: \mathrm{B}$ ratios, with a coefficient of 0.9239 . However, no correlations between growth parameters and BP, RP, or R:B ratios were observed in red mustard. The plant height and leaf area of green mustard decreased by $15 \%$ and $22 \%$, respectively, when BP increased from $12 \%$ to $49 \%$ (Fig. 4C). The SLA of green mustard was lowest under $49 \%$ BP, whereas the inclusion of $\mathrm{G}$ wavelength decreased its SLA under $24 \%$ BP. The inclusion of G wavelengths increased plant height in green mustard under $12 \% \mathrm{BP}$ but decreased it under $24 \% \mathrm{BP}$. Light quality showed no influence on the plant height or SLA of red mustard, whereas the inclusion of $\mathrm{G}$ wavelengths decreased the leaf area under 24\% BP (Fig. 4D).

Among the three R\&B light combinations, the shoot FW of green mustard was highest under $\mathrm{R}_{88} \mathrm{~B}_{12}$, but it showed no difference between $\mathrm{R}_{76} \mathrm{~B}_{24}$ and $\mathrm{R}_{51} \mathrm{~B}_{49}$ (Fig. $5 \mathrm{C}$ ). The shoot $\mathrm{FW}$ 

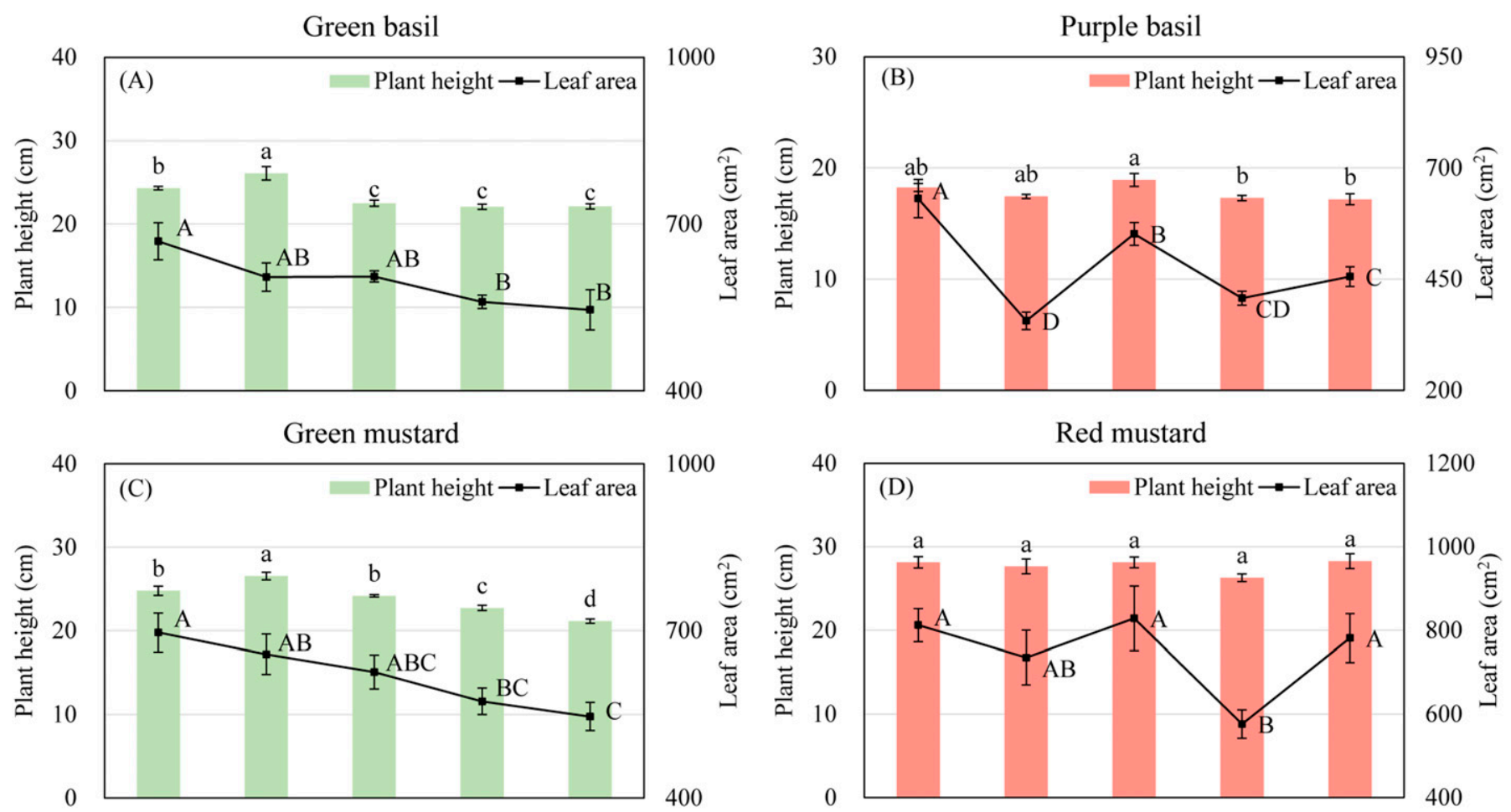

1000
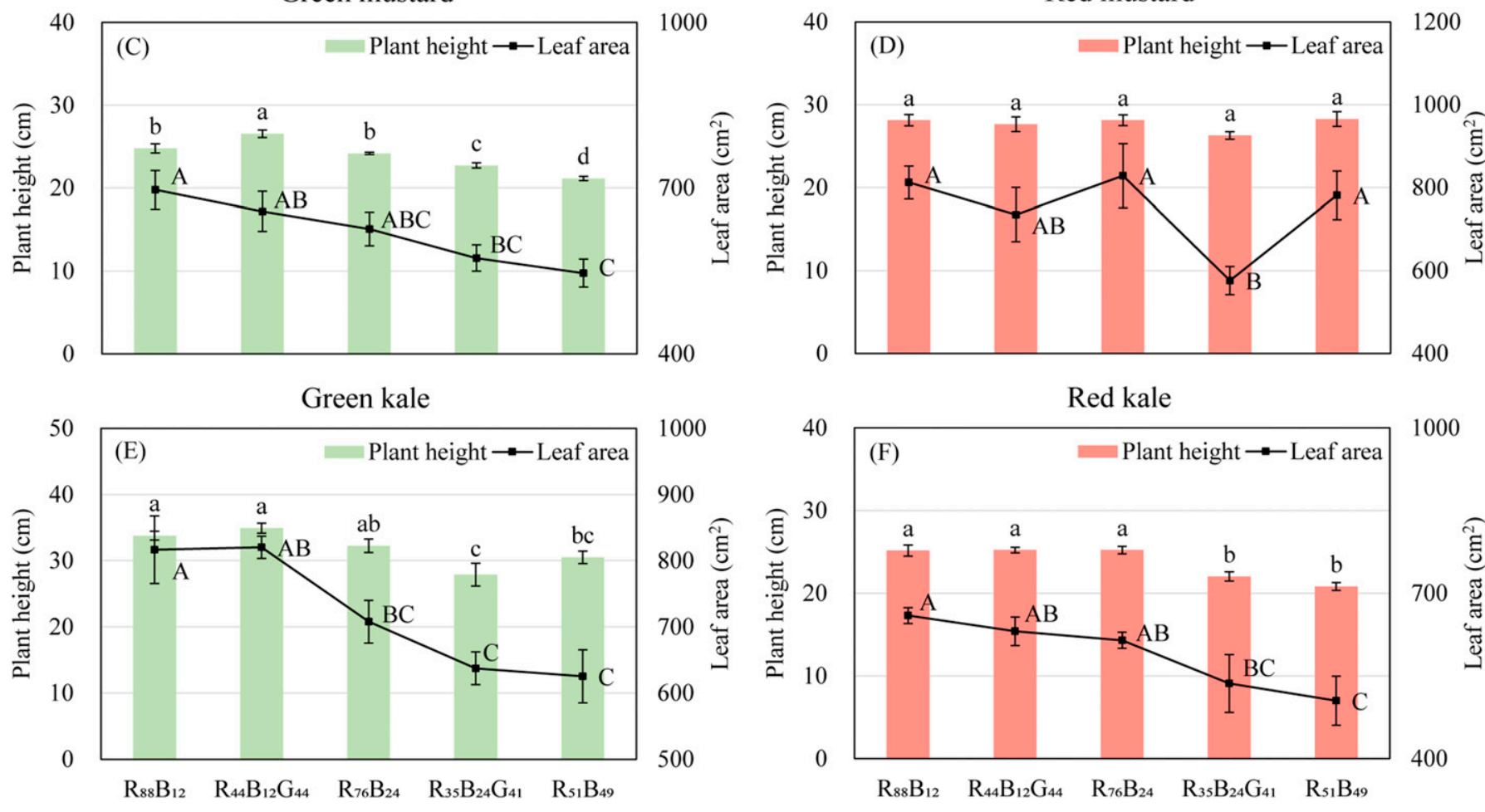

1000
900
800
700
600
500

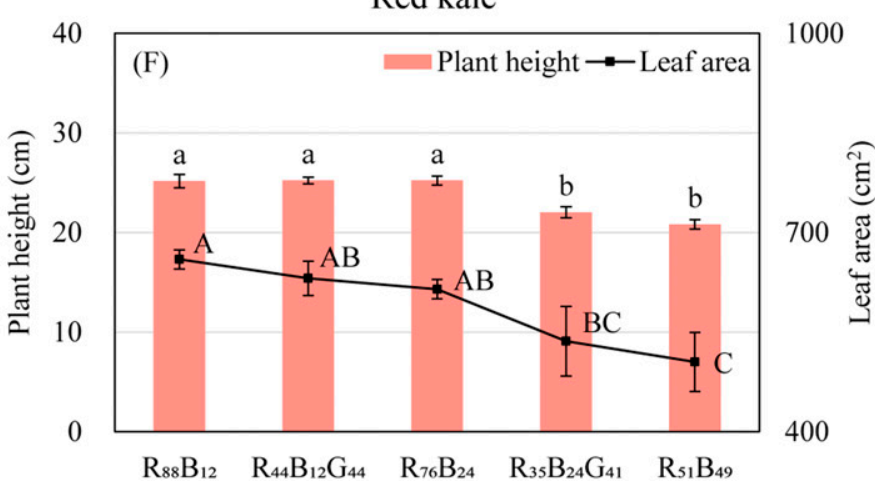

Fig. 4. Plant height and leaf area of (A) green basil 'Improved Genovese Compact', (B) purple basil 'Red Rubin', (C) green mustard 'Amara', (D) red mustard 'Red Giant', (E) green kale 'Siberian', and (F) red kale 'Scarlet' grown under three combined red (R) and blue (B) light combinations, $\mathrm{R}_{88} \mathrm{~B}_{12}$ (the proportions of R and B wavelengths were $88 \%$ and $12 \%$, respectively), $R_{76} B_{24}$ (the proportions of $R$ and $B$ wavelengths were $76 \%$ and $24 \%$, respectively), and $R_{51} B_{49}$ (the proportions of $\mathrm{R}$ and $\mathrm{B}$ wavelengths were $51 \%$ and $49 \%$, respectively) and two white light combinations, $\mathrm{R}_{44} \mathrm{~B}_{12} \mathrm{G}_{44}$ [white light-emitting diode with $\mathrm{R}$, $\mathrm{B}$, and green (G) wavelength proportions of $44 \%, 12 \%$, and $44 \%$, respectively] and $\mathrm{R}_{35} \mathrm{~B}_{24} \mathrm{G}_{41}$ (white fluorescent light with $\mathrm{R}, \mathrm{B}$, and $\mathrm{G}$ wavelength proportions of $35 \%, 24 \%$, and $41 \%$, respectively). Means followed by different lowercase and uppercase letters indicate a significant difference for plant height and leaf area, respectively, according to one-way analysis of variance $(P \leq 0.05)$.

of red mustard was unaffected by BP and RP (Fig. 5D), whereas the shoot FW of green mustard was positively correlated with $\mathrm{R}: \mathrm{B}$ ratios, with a coefficient of 0.9100 . The shoot $\mathrm{FW}$ of green mustard tended to decrease with the inclusion of $G$ wavelengths, but the difference was not significant. The shoot DW of green mustard was unaffected by light quality treatments. The shoot FW and DW of red mustard were $32 \%$ and $29 \%$ lower with the inclusion of $\mathrm{G}$ wavelengths under $24 \% \mathrm{BP}$, respectively. No correlations between plant yield and BP were observed in mustard.

Among the three R\&B light combinations, the phenolics concentration in green mustard increased with increasing BP, whereas its other phytochemical concentrations were unaffected by BP (Table 1). In red mustard, the anthocyanin concentration was highest under $\mathrm{R}_{88} \mathrm{~B}_{12}$ and $\mathrm{R}_{51} \mathrm{~B}_{49}$ and lowest under $\mathrm{R}_{76} \mathrm{~B}_{24}$. The other phytochemical concentrations in red mustard were unaffected by BP (Table 1). Under $12 \%$ BP, the phenolics concentration in green mustard decreased with the inclusion of $\mathrm{G}$ wavelengths, whereas it showed no effects on the other phytochemical concentrations, regardless of cultivar or BP (Table 1). The anthocyanin concentration in green mustard was negatively correlated with RP, with a coefficient of -0.9569 , and its phenolics concentration was negatively correlated with R:B ratios, with a coefficient of -0.8963 . No correlations between phytochemical parameters and BP, RP, or $\mathrm{R}: \mathrm{B}$ ratio were observed in red mustard.

Among the three R\&B light combinations, the total amounts of anthocyanin and flavonoids in green mustard were both lowest under $49 \%$ BP, whereas other total amounts of phytochemicals were unaffected by BP, regardless of cultivar (Table 
Green basil
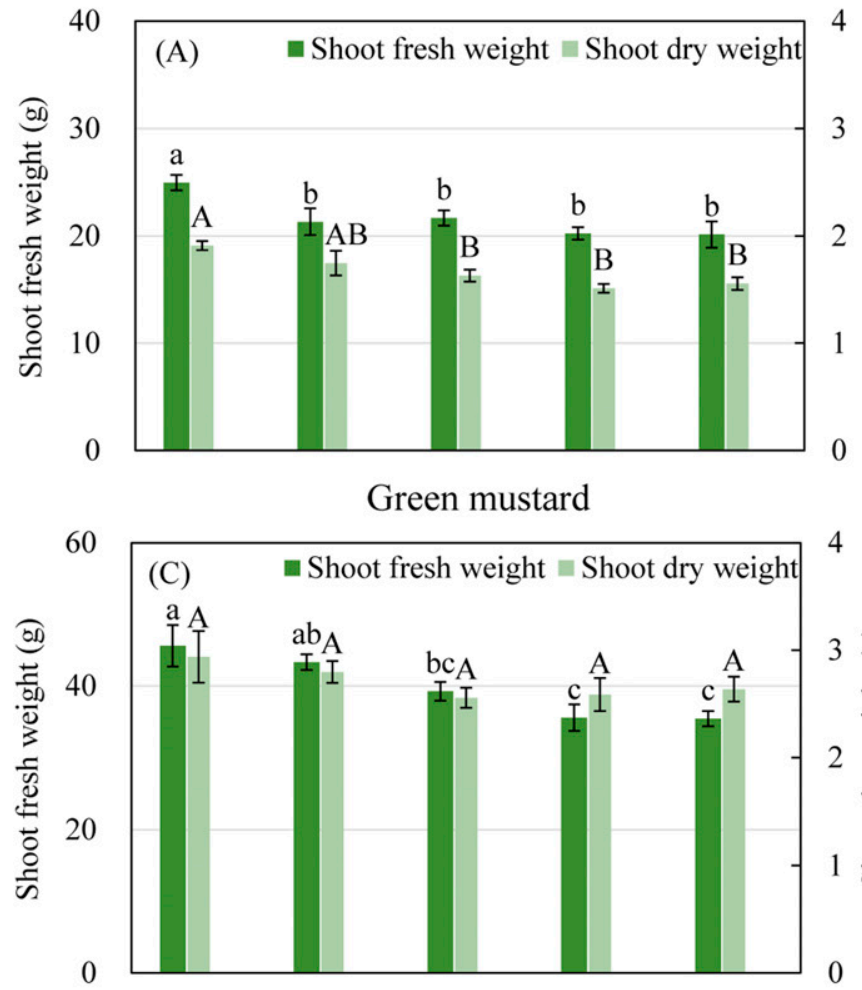

4

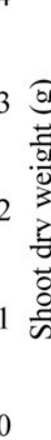

Green kale

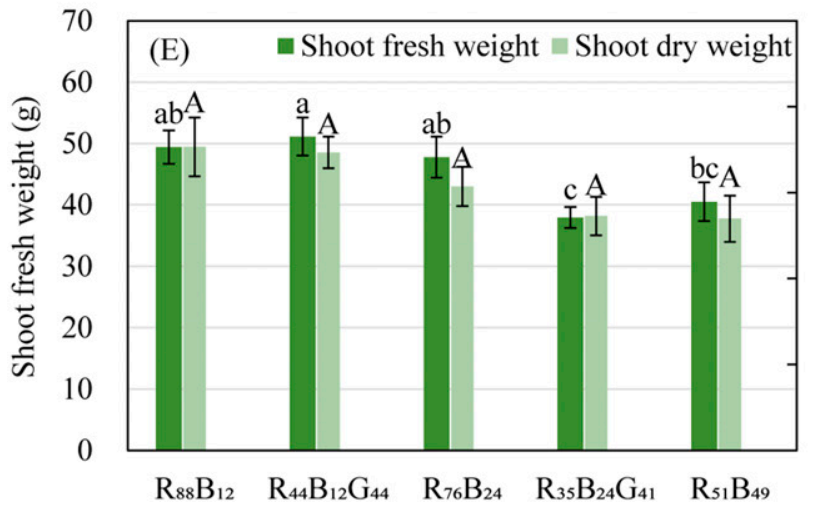

Purple basil
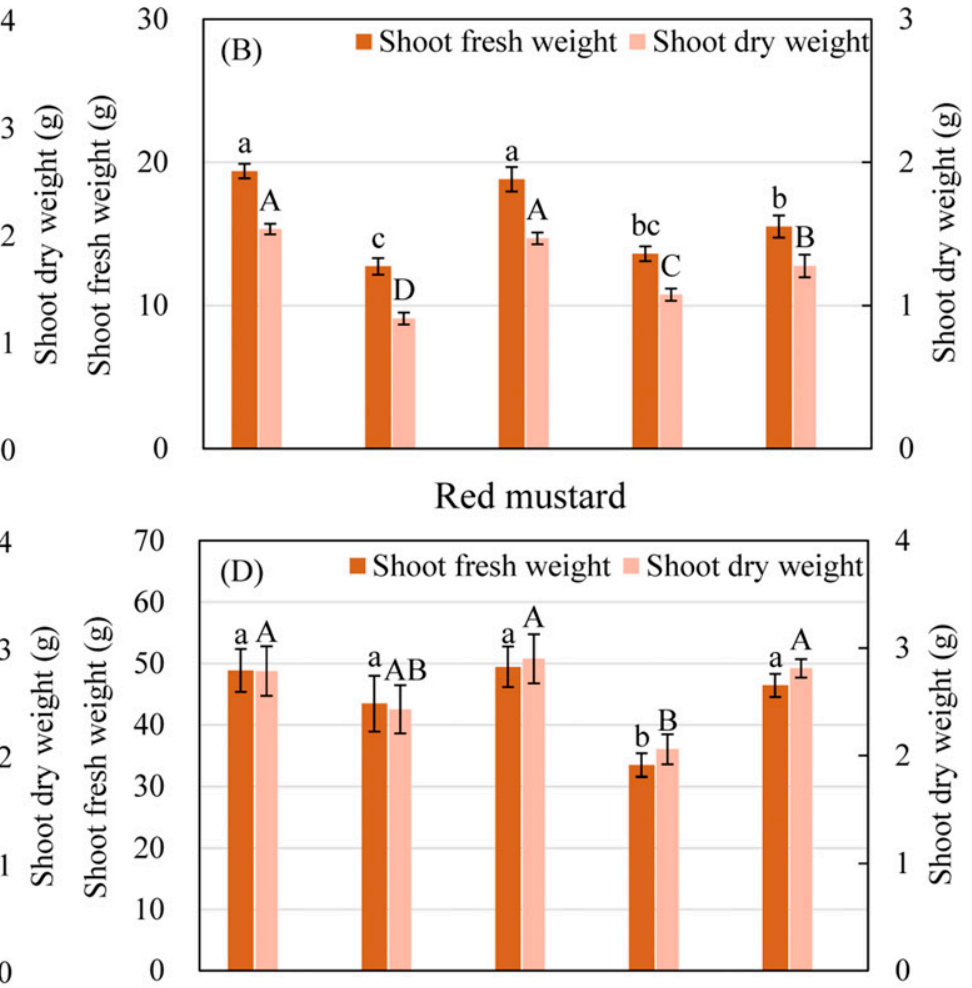

Red kale

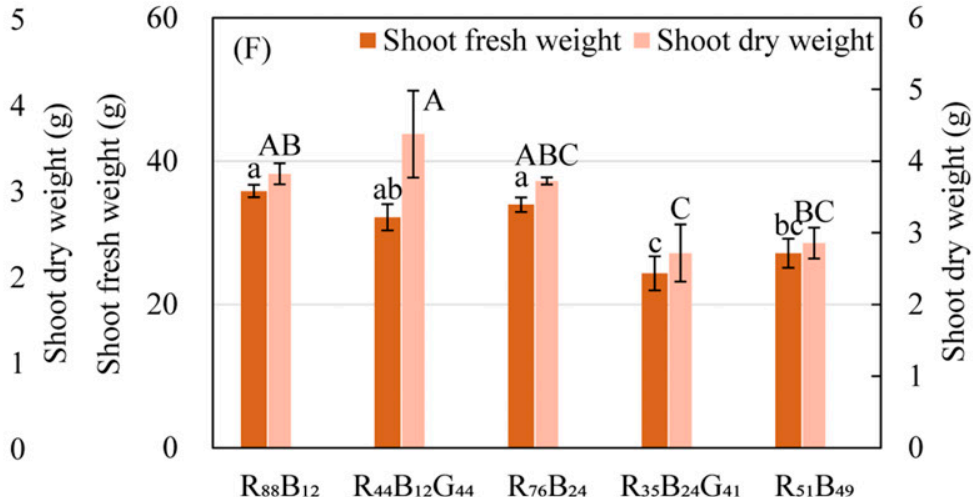

Fig. 5. Shoot fresh weight and dry weight of (A) green basil 'Improved Genovese Compact', (B) purple basil 'Red Rubin', (C) green mustard 'Amara', (D) red mustard 'Red Giant', (E) green kale 'Siberian', and (F) red kale 'Scarlet' grown under three combined red (R) and blue (B) light combinations, $\mathrm{R}_{88} \mathrm{~B}_{12}$ (the proportions of $R$ and $B$ wavelengths were $88 \%$ and $12 \%$, respectively), $R_{76} B_{24}$ (the proportions of $R$ and $B$ wavelengths were $76 \%$ and $24 \%$, respectively), and $R_{51}$ $\mathrm{B}_{49}$ (the proportions of $\mathrm{R}$ and $\mathrm{B}$ wavelengths were $51 \%$ and $49 \%$, respectively), and two white light combinations, $\mathrm{R}_{44} \mathrm{~B}_{12} \mathrm{G}_{44}$ [white light-emitting diode with $\mathrm{R}$, $\mathrm{B}$, and green $(\mathrm{G})$ wavelength proportions of $44 \%, 12 \%$, and $44 \%$, respectively] and $\mathrm{R}_{35} \mathrm{~B}_{24} \mathrm{G}_{41}$ (white fluorescent light with $\mathrm{R}, \mathrm{B}$, and $\mathrm{G}$ wavelength proportions of $35 \%, 24 \%$, and $41 \%$, respectively). Means followed by different lowercase and uppercase letters indicate a significant difference for shoot fresh weight and dry weight, respectively, according to one-way analysis of variance $(P \leq 0.05)$.

2). Under $12 \% \mathrm{BP}$, the total amounts of anthocyanin and phenolics in green mustard increased with the inclusion of $\mathrm{G}$ wavelengths, whereas other total amounts of phytochemicals in green mustard were unaffected, regardless of BP. In red mustard, all total amounts of phytochemicals decreased with the inclusion of $\mathrm{G}$ wavelengths, regardless of $\mathrm{BP}$, except with the total amount of flavonoids under 12\% BP (Table 2).

\section{Morphological and physiological responses in kale to different RP, BP, and GP}

In green kale, comparative $P_{n}$ was highest under treatments $R_{51}$ $\mathrm{B}_{49}$ and $\mathrm{R}_{76} \mathrm{~B}_{24}$ (Fig. 2), which was positively correlated with BP, with a coefficient of 0.9279 , and showed no relationship with RP or R:B ratios. The SPAD reading of green kale was unaffected by light quality treatments (Fig. 3). In red kale, comparative $P_{n}$ was not influenced by BP among three R\&B light combinations, whereas the inclusion of $\mathrm{G}$ wavelengths decreased comparative $\mathrm{P}_{\mathrm{n}}$ under $24 \%$ BP (Fig. 2). Increasing BP from $12 \%$ to $24 \%$ increased the SPAD of red kale among three R\&B light combinations. Under $12 \% \mathrm{BP}$, the inclusion of $\mathrm{G}$ wavelengths increased the SPAD of red kale by $15 \%$; however, under $24 \% \mathrm{BP}$, the inclusion of $\mathrm{G}$ wavelengths showed no effects (Fig. 3).

The plant height and leaf area of green and red kale both decreased with increasing BP among the three $R \& B$ light 
Table 1. Concentrations of anthocyanin, phenolics, and flavonoids and antioxidant capacity of green basil 'Improved Genovese Compact', purple basil 'Red Rubin', green mustard 'Amara', red mustard 'Red Giant', green kale 'Siberian', and red kale 'Scarlet' grown under five light quality treatments, which include three combined red $(\mathrm{R})$ and blue $(\mathrm{B})$ light combinations, $\mathrm{R}_{88} \mathrm{~B}_{12}$ (the proportion of $\mathrm{R}$ and $\mathrm{B}$ wavelength was $88 \%$ and $12 \%$, respectively), $R_{76} B_{24}$ (the proportion of $R$ and $B$ wavelength was $76 \%$ and $24 \%$, respectively), and $R_{51} B_{49}($ the proportion of $R$ and $\mathrm{B}$ wavelength was $51 \%$ and $49 \%$, respectively) and two white light, $\mathrm{R}_{44} \mathrm{~B}_{12} \mathrm{G}_{44}$ [white light emitting-diode with $\mathrm{R}$, $\mathrm{B}$, and green (G) wavelength proportion of $44 \%, 12 \%$, and $44 \%$, respectively] and $\mathrm{R}_{35} \mathrm{~B}_{24} \mathrm{G}_{41}$ (white fluorescent light with $\mathrm{R}$, $\mathrm{B}$, and $\mathrm{G}$ wavelength proportion of $35 \%, 24 \%$, and $41 \%$, respectively).

\begin{tabular}{|c|c|c|c|c|c|}
\hline Cultivar & Treatment & $\begin{array}{l}\text { Anthocyanin concn } \\
(\mathrm{mg} / 100 \mathrm{~g})\end{array}$ & $\begin{array}{l}\text { Phenolics concn } \\
\left(\mathrm{mg} \cdot \mathrm{g}^{-1}\right)\end{array}$ & $\begin{array}{c}\text { Flavonoids concn } \\
\left(\mathrm{mg} \cdot \mathrm{g}^{-1}\right)\end{array}$ & $\begin{array}{c}\text { Antioxidant capacity } \\
(\mathrm{mg} / 100 \mathrm{~g})\end{array}$ \\
\hline \multirow[t]{4}{*}{ Green basil } & $\mathrm{R}_{88} \mathrm{~B}_{12}$ & $2.54 \mathrm{a}^{\mathrm{z}}$ & $1.28 \mathrm{a}$ & $0.49 \mathrm{bc}$ & $295 \mathrm{~b}$ \\
\hline & $\mathrm{R}_{44} \mathrm{~B}_{12} \mathrm{G}_{44}$ & $2.77 \mathrm{a}$ & $1.04 \mathrm{~b}$ & $0.48 \mathrm{bc}$ & $290 \mathrm{bc}$ \\
\hline & $\mathrm{R}_{35} \mathrm{~B}_{24} \mathrm{G}_{41}$ & $2.95 \mathrm{a}$ & $1.01 \mathrm{~b}$ & $0.40 \mathrm{c}$ & $249 c$ \\
\hline & $\mathrm{R}_{51} \mathrm{~B}_{49}$ & $2.75 \mathrm{a}$ & $1.30 \mathrm{a}$ & $0.53 \mathrm{~b}$ & $251 \mathrm{bc}$ \\
\hline \multirow[t]{4}{*}{ Purple basil } & $\mathrm{R}_{88} \mathrm{~B}_{12}$ & $13.5 \mathrm{a}$ & $2.81 \mathrm{c}$ & $2.43 \mathrm{~b}$ & $1570 \mathrm{~b}$ \\
\hline & $\mathrm{R}_{76} \mathrm{~B}_{24}$ & $13.8 \mathrm{a}$ & $3.21 \mathrm{~b}$ & $2.70 \mathrm{a}$ & $1755 \mathrm{a}$ \\
\hline & $\mathrm{R}_{35} \mathrm{~B}_{24} \mathrm{G}_{41}$ & $13.9 \mathrm{a}$ & $2.62 \mathrm{c}$ & $1.87 \mathrm{c}$ & $1229 \mathrm{~d}$ \\
\hline & $\mathrm{R}_{51} \mathrm{~B}_{49}$ & $14.1 \mathrm{a}$ & $3.47 \mathrm{a}$ & $2.70 \mathrm{a}$ & $1873 \mathrm{a}$ \\
\hline \multirow[t]{3}{*}{ Green mustard } & $\mathrm{R}_{88} \mathrm{~B}_{12}$ & $7.22 \mathrm{a}$ & $0.98 \mathrm{c}$ & $0.87 \mathrm{a}$ & $176 \mathrm{a}$ \\
\hline & $\mathrm{R}_{44} \mathrm{~B}_{12} \mathrm{G}_{44}$ & $7.90 \mathrm{a}$ & $1.12 \mathrm{~b}$ & $0.96 \mathrm{a}$ & $151 \mathrm{a}$ \\
\hline & $\mathrm{R}_{76} \mathrm{~B}_{24}$ & $7.53 \mathrm{a}$ & $1.13 \mathrm{~b}$ & $0.96 \mathrm{a}$ & $186 \mathrm{a}$ \\
\hline \multirow{3}{*}{ Red mustard } & $\mathrm{R}_{76} \mathrm{~B}_{24}$ & $9.47 \mathrm{~b}$ & $1.21 \mathrm{a}$ & $0.87 \mathrm{a}$ & $213 \mathrm{ab}$ \\
\hline & $\mathrm{R}_{35} \mathrm{~B}_{24} \mathrm{G}_{41}$ & $9.90 \mathrm{ab}$ & $1.27 \mathrm{a}$ & $0.85 \mathrm{a}$ & $232 \mathrm{a}$ \\
\hline & $\mathrm{R}_{51} \mathrm{~B}_{49}$ & $10.27 \mathrm{a}$ & $1.26 \mathrm{a}$ & $0.90 \mathrm{a}$ & $220 \mathrm{a}$ \\
\hline \multirow[t]{5}{*}{ Green kale } & $\mathrm{R}_{88} \mathrm{~B}_{12}$ & $6.74 \mathrm{~b}$ & $0.75 \mathrm{c}$ & $0.97 \mathrm{a}$ & $141 \mathrm{bc}$ \\
\hline & $\mathrm{R}_{44} \mathrm{~B}_{12} \mathrm{G}_{44}$ & $7.51 \mathrm{a}$ & $0.79 \mathrm{bc}$ & $1.01 \mathrm{a}$ & $112 \mathrm{c}$ \\
\hline & $\mathrm{R}_{76} \mathrm{~B}_{24}$ & $7.15 \mathrm{ab}$ & $0.81 \mathrm{bc}$ & $0.97 \mathrm{a}$ & $121 \mathrm{bc}$ \\
\hline & $\mathrm{R}_{35} \mathrm{~B}_{24} \mathrm{G}_{41}$ & $7.61 \mathrm{a}$ & $1.11 \mathrm{a}$ & $1.07 \mathrm{a}$ & $178 \mathrm{a}$ \\
\hline & $\mathrm{R}_{51} \mathrm{~B}_{49}$ & $7.44 \mathrm{a}$ & $0.98 \mathrm{ab}$ & $1.04 \mathrm{a}$ & $151 \mathrm{ab}$ \\
\hline \multirow[t]{3}{*}{ Red kale } & $\mathrm{R}_{88} \mathrm{~B}_{12}$ & $9.73 \mathrm{a}$ & $1.40 \mathrm{bc}$ & $1.22 \mathrm{a}$ & 279 a \\
\hline & $\mathrm{R}_{44} \mathrm{~B}_{12} \mathrm{G}_{44}$ & $9.51 \mathrm{a}$ & $1.22 \mathrm{c}$ & $1.17 \mathrm{a}$ & $210 \mathrm{~b}$ \\
\hline & $\mathrm{R}_{76} \mathrm{~B}_{24}$ & $9.61 \mathrm{a}$ & $1.47 \mathrm{ab}$ & $1.26 \mathrm{a}$ & $294 \mathrm{a}$ \\
\hline
\end{tabular}

${ }^{\mathrm{z}}$ Means followed by the same lowercase letters are not significantly different according to one-way analysis of variance $(P \leq 0.05)$.

combinations (Fig. 4E and F). The leaf area of red kale was negatively correlated with BP, with a coefficient of -0.8831 (Fig. 4F). The SLA of green kale and red kale were unaffected by light quality treatments. The inclusion of $\mathrm{G}$ wavelengths decreased plant height under $24 \% \mathrm{BP}$, regardless of cultivar, whereas it showed no effects under $12 \%$ BP (Fig. 4E and F). The inclusion of $\mathrm{G}$ wavelengths showed no effects on leaf area, regardless of cultivar or BP.

Among the three R\&B light combinations, the shoot FW of green kale and red kale decreased by $18 \%$ and $24 \%$, respectively, when BP increased from $12 \%$ to $49 \%$ (Fig. 5E and F). No correlations between plant yield and BP, RP, or R:B ratios were observed in green kale or red kale. Shoot DW of green kale and red kale were unaffected by BP. Under $24 \%$ BP, the inclusion of $\mathrm{G}$ wavelengths decreased the shoot $\mathrm{FW}$ by $21 \%$ to $28 \%$, regardless of cultivar, but it showed no effects under $12 \% \mathrm{BP}$.

Among the three $\mathrm{R} \& \mathrm{~B}$ light combinations, the anthocyanin concentration and phenolics concentration in and antioxidant capacity of green kale were highest under $R_{76} B_{24}$ and $R_{51} B_{49}$, whereas the flavonoids concentration was unaffected by light quality treatments (Table 1). A similar trend was observed for the phenolics concentration in red kale, but its anthocyanin concentration, flavonoids concentration, and antioxidant capacity were unaffected by changing BP (Table 1). Under $12 \%$ BP, the inclusion of $\mathrm{G}$ wavelengths increased the anthocyanin concentration in green kale and decreased the antioxidant capacity of red kale, but it showed no effects on the other phytochemical concentrations. Under $24 \%$ BP, the inclusion of G wavelengths increased the phenolics concentration in and antioxidant capacity of green basil, but it showed no effects on the other phytochemical concentrations, regardless of cultivar. The anthocyanin concentration in green kale was negatively correlated with RP and R:B ratios, with coefficients of -0.9689 and -0.8948 , respectively, whereas its flavonoids concentration was negatively correlated with RP, with a coefficient of -0.8957 . No correlations between phytochemical parameters and $\mathrm{BP}, \mathrm{RP}$, or $\mathrm{R}: \mathrm{B}$ ratio were observed in red kale.

Among the three $\mathrm{R} \& \mathrm{~B}$ light combinations, increases of $\mathrm{BP}$ showed no effects on the total amounts of phenolics and flavonoids in and the antioxidant capacity of green kale, but its total amount of anthocyanin was lowest under treatment $\mathrm{R}_{51} \mathrm{~B}_{49}$ (Table 2). In red kale, the total amount of anthocyanin was highest under 
Table 2. Total amounts of anthocyanin, phenolics, and flavonoids and antioxidant capacity per plant of green basil 'Improved Genovese Compact', purple basil 'Red Rubin', green mustard 'Amara', red mustard 'Red Giant', green kale 'Siberian', and red kale 'Scarlet' grown under five light quality treatments, which include three combined red (R) and blue (B) light combinations, $\mathrm{R}_{88} \mathrm{~B}_{12}$ (the proportion of $\mathrm{R}$ and $\mathrm{B}$ wavelength was $88 \%$ and $12 \%$, respectively), $\mathrm{R}_{76} \mathrm{~B}_{24}$ (the proportion of $\mathrm{R}$ and B wavelength was $76 \%$ and $24 \%$, respectively), and $\mathrm{R}_{51} \mathrm{~B}_{49}$ (the proportion of $\mathrm{R}$ and $\mathrm{B}$ wavelength was $51 \%$ and $49 \%$, respectively) and two white light, $\mathrm{R}_{44} \mathrm{~B}_{12} \mathrm{G}_{44}$ [white light emitting-diode with $\mathrm{R}$, $\mathrm{B}$, and green $(\mathrm{G})$ wavelength proportion of $44 \%, 12 \%$, and $44 \%$, respectively] and $\mathrm{R}_{35} \mathrm{~B}_{24} \mathrm{G}_{41}$ (white fluorescent light with $\mathrm{R}, \mathrm{B}$, and $\mathrm{G}$ wavelength proportion of $35 \%, 24 \%$, and $41 \%$, respectively).

\begin{tabular}{|c|c|c|c|c|c|}
\hline \multirow[b]{2}{*}{ Cultivar } & \multirow[b]{2}{*}{ Treatment } & \multicolumn{4}{|c|}{ Total amount of phytochemicals (mg/plant) } \\
\hline & & Anthocyanin & Phenolics & Flavonoids & Antioxidant capacity \\
\hline \multirow[t]{5}{*}{ Green basil } & $\mathrm{R}_{88} \mathrm{~B}_{12}$ & $0.51 \mathrm{a}^{\mathrm{z}}$ & $25 \mathrm{a}$ & $10 \mathrm{~b}$ & $59 \mathrm{~b}$ \\
\hline & $\mathrm{R}_{44} \mathrm{~B}_{12} \mathrm{G}_{44}$ & $0.46 \mathrm{ab}$ & $18 \mathrm{c}$ & $8 \mathrm{bc}$ & $49 \mathrm{c}$ \\
\hline & $\mathrm{R}_{76} \mathrm{~B}_{24}$ & $0.49 \mathrm{ab}$ & $24 \mathrm{ab}$ & $15 \mathrm{a}$ & $68 \mathrm{a}$ \\
\hline & $\mathrm{R}_{35} \mathrm{~B}_{24} \mathrm{G}_{41}$ & $0.48 \mathrm{ab}$ & $17 \mathrm{c}$ & $7 \mathrm{c}$ & $41 \mathrm{~d}$ \\
\hline & $\mathrm{R}_{51} \mathrm{~B}_{49}$ & $0.44 \mathrm{~b}$ & $21 \mathrm{~b}$ & $9 \mathrm{~b}$ & $40 \mathrm{~d}$ \\
\hline \multirow[t]{5}{*}{ Purple basil } & $\mathrm{R}_{88} \mathrm{~B}_{12}$ & $2.01 \mathrm{a}$ & $42 \mathrm{~b}$ & $36 \mathrm{~b}$ & $234 \mathrm{~b}$ \\
\hline & $\mathrm{R}_{44} \mathrm{~B}_{12} \mathrm{G}_{44}$ & $1.39 \mathrm{c}$ & $26 \mathrm{c}$ & $19 \mathrm{~d}$ & $138 \mathrm{c}$ \\
\hline & $\mathrm{R}_{76} \mathrm{~B}_{24}$ & $2.01 \mathrm{a}$ & $47 \mathrm{a}$ & 39 a & $255 \mathrm{a}$ \\
\hline & $\mathrm{R}_{35} \mathrm{~B}_{24} \mathrm{G}_{41}$ & $1.46 \mathrm{c}$ & $27 \mathrm{c}$ & $20 \mathrm{~d}$ & $129 \mathrm{c}$ \\
\hline & $\mathrm{R}_{51} \mathrm{~B}_{49}$ & $1.71 \mathrm{~b}$ & $42 \mathrm{~b}$ & $33 \mathrm{c}$ & $227 \mathrm{~b}$ \\
\hline \multirow[t]{5}{*}{ Green mustard } & $\mathrm{R}_{88} \mathrm{~B}_{12}$ & $3.14 \mathrm{~b}$ & $43 \mathrm{~b}$ & $38 \mathrm{ab}$ & $76 \mathrm{a}$ \\
\hline & $\mathrm{R}_{44} \mathrm{~B}_{12} \mathrm{G}_{44}$ & $3.42 \mathrm{a}$ & $49 \mathrm{a}$ & $41 \mathrm{a}$ & $65 \mathrm{a}$ \\
\hline & $\mathrm{R}_{76} \mathrm{~B}_{24}$ & $2.96 \mathrm{bc}$ & $45 \mathrm{ab}$ & $38 \mathrm{ab}$ & $74 \mathrm{a}$ \\
\hline & $\mathrm{R}_{35} \mathrm{~B}_{24} \mathrm{G}_{41}$ & $2.80 \mathrm{~cd}$ & $40 \mathrm{~b}$ & $34 \mathrm{bc}$ & $61 \mathrm{a}$ \\
\hline & $\mathrm{R}_{51} \mathrm{~B}_{49}$ & $2.67 \mathrm{~d}$ & $42 \mathrm{~b}$ & $31 \mathrm{c}$ & $69 \mathrm{a}$ \\
\hline \multirow[t]{5}{*}{ Red mustard } & $\mathrm{R}_{88} \mathrm{~B}_{12}$ & $4.70 \mathrm{a}$ & $58 \mathrm{a}$ & $41 \mathrm{ab}$ & $103 \mathrm{a}$ \\
\hline & $\mathrm{R}_{44} \mathrm{~B}_{12} \mathrm{G}_{44}$ & $4.16 \mathrm{~b}$ & $47 \mathrm{~b}$ & $37 \mathrm{~b}$ & $63 \mathrm{~b}$ \\
\hline & $\mathrm{R}_{76} \mathrm{~B}_{24}$ & $4.85 \mathrm{a}$ & $62 \mathrm{a}$ & $42 \mathrm{a}$ & $101 \mathrm{a}$ \\
\hline & $\mathrm{R}_{35} \mathrm{~B}_{24} \mathrm{G}_{41}$ & $3.32 \mathrm{c}$ & $43 \mathrm{~b}$ & $29 \mathrm{c}$ & $78 \mathrm{~b}$ \\
\hline & $\mathrm{R}_{51} \mathrm{~B}_{49}$ & $4.76 \mathrm{a}$ & $59 \mathrm{a}$ & $42 \mathrm{a}$ & $102 \mathrm{a}$ \\
\hline \multirow[t]{5}{*}{ Green kale } & $\mathrm{R}_{88} \mathrm{~B}_{12}$ & $3.33 \mathrm{~b}$ & $37 \mathrm{a}$ & $48 \mathrm{ab}$ & $70 \mathrm{a}$ \\
\hline & $\mathrm{R}_{44} \mathrm{~B}_{12} \mathrm{G}_{44}$ & $3.84 \mathrm{a}$ & $40 \mathrm{a}$ & $52 \mathrm{a}$ & $57 \mathrm{a}$ \\
\hline & $\mathrm{R}_{76} \mathrm{~B}_{24}$ & $3.42 \mathrm{~b}$ & $39 \mathrm{a}$ & $46 \mathrm{abc}$ & $58 \mathrm{a}$ \\
\hline & $\mathrm{R}_{35} \mathrm{~B}_{24} \mathrm{G}_{41}$ & $2.89 \mathrm{c}$ & $42 \mathrm{a}$ & $41 \mathrm{c}$ & $67 \mathrm{a}$ \\
\hline & $\mathrm{R}_{51} \mathrm{~B}_{49}$ & $3.01 \mathrm{c}$ & $40 \mathrm{a}$ & $42 \mathrm{bc}$ & $61 \mathrm{a}$ \\
\hline \multirow[t]{5}{*}{ Red kale } & $\mathrm{R}_{88} \mathrm{~B}_{12}$ & $3.48 \mathrm{a}$ & $50 \mathrm{a}$ & $44 \mathrm{a}$ & $100 \mathrm{a}$ \\
\hline & $\mathrm{R}_{44} \mathrm{~B}_{12} \mathrm{G}_{44}$ & $3.06 \mathrm{c}$ & $39 \mathrm{~b}$ & $38 \mathrm{~b}$ & $68 \mathrm{c}$ \\
\hline & $\mathrm{R}_{76} \mathrm{~B}_{24}$ & $3.26 \mathrm{~b}$ & $50 \mathrm{a}$ & $43 \mathrm{a}$ & $100 \mathrm{a}$ \\
\hline & $\mathrm{R}_{35} \mathrm{~B}_{24} \mathrm{G}_{41}$ & $2.47 \mathrm{e}$ & $40 \mathrm{~b}$ & $27 \mathrm{~d}$ & $76 \mathrm{bc}$ \\
\hline & $\mathrm{R}_{51} \mathrm{~B}_{49}$ & $2.65 \mathrm{~d}$ & $45 \mathrm{ab}$ & $33 \mathrm{c}$ & $91 \mathrm{ab}$ \\
\hline
\end{tabular}

$\overline{\mathrm{z}}$ Means followed by the same lowercase letters are not significantly different according to one-way analysis of variance $(P \leq 0.05)$.

$\mathrm{R}_{88} \mathrm{~B}_{12}$, followed by $\mathrm{R}_{76} \mathrm{~B}_{24}$, and lowest under $\mathrm{R}_{51} \mathrm{~B}_{49}$, whereas the total amount of flavonoids was highest under $\mathrm{R}_{88} \mathrm{~B}_{12}$ and $\mathrm{R}_{76}$ $\mathrm{B}_{24}$ and lowest under $\mathrm{R}_{51} \mathrm{~B}_{49}$. The total amount of phenolics in and antioxidant capacity of red kale were unaffected by BP. The inclusion of $\mathrm{G}$ wavelengths increased the total amount of anthocyanin in green kale under $12 \% \mathrm{BP}$, whereas it decreased its total amount of anthocyanin under $24 \%$ BP, but it showed no effects on the other total amounts of phytochemicals in green kale, regardless of BP. In red kale, the inclusion of $G$ wavelengths decreased all total amounts of phytochemicals, regardless of BP (Table 2).

\section{Discussion}

\section{Photosynthesis and chlorophyll content as influenced by RP, BP,} and GP

Although responses of plant photosynthesis to B wavelengths are species-specific and cultivar-specific, many studies indicated that supplementing $\mathrm{R}$ with $B$ wavelengths increased plant photosynthetic performance by enriching chlorophyll content, increasing stomatal density, and improving enzyme activity (Bugbee, 2016; Fan et al., 2013; Li, 2010). The chlorophyll concentration, stomatal conductance, and $\mathrm{P}_{\mathrm{n}}$ in cucumber were positively correlated with BP ranging from $0 \%$ to $80 \%$ under $\mathrm{R} \& \mathrm{~B}$ light combination (Hernandez et al., 2016; Hogewoning et al., 2010). In this study, we measured the effects of different waveband proportions on plant photosynthetic capacity, and the comparative $P_{n}$ of purple basil and green kale were positively correlated with BP. This was supported by studies by Kinoshita et al. (2001) and Zeiger et al. (2002), in which the $\mathrm{B}$ wavelength alone or R\&B light combination increased stomatal density and aperture, which may increase plants' capacity for $\mathrm{CO}_{2}$ uptake and ultimately increase photosynthesis. Furthermore, activities of photosynthetic enzymes (e.g., Rubisco) and biosynthetic intermediates of chlorophylls (e.g., 5-aminolevulinic acid, protoporphyrin IX, Mg-protoporphyrin IX, and protochlorophyllide) increased under enriched B wavelengths (Bondada and Syvertsen, 2003; Fan et al., 2013; Li, 2010). Increasing B wavelengths can stimulate high irradiance leaf characteristics even under constant PPFD, performing as improved $\mathrm{P}_{\mathrm{n}}$ with increasing BP under constant PPFD (Hogewoning et al., 2010). However, plant responses to B wavelength are different at whole-plant canopy and single-leaf scales (Craver et al., 2020). Overall plant growth under high BP is inhibited due to B wavelength-inhibited extension growth, whereas single-leaf photosynthesis is promoted (Bugbee, 2016; Craver et al., 2020). Results of the present study support these findings, and inhibition of overall plant growth by $B$ wavelengths is presented later.

In this study, the inclusion of $\mathrm{G}$ wavelengths decreased the comparative $\mathrm{P}_{\mathrm{n}}$ in red kale, and a similar trend was observed in green kale and mustard (Fig. 2). It was postulated that $G$ wavelength deactivation of $\mathrm{B}$ wavelength-activated cryptochrome removes the signal for suppression of abscisic acid production in guard cells, resulting in a decreased stomatal aperture and stomatal opening, subsequently decreasing $P_{n}$ (Meng et al., 2019). In particular, the flavin chromophore of cryptochrome is driven to a biologically active semi-reduced form by $B$ wavelengths, which is shifted to a deactivated reduced state by the absorption of $\mathrm{G}$ wavelengths (Banerjee 
et al., 2007; Bouly et al., 2007). Similarly, Kang et al. (2016) reported that the inclusion of $10 \%$ GP decreased $P_{n}$ and chlorophyll concentrations in 'Green Skirt' lettuce compared with plants grown under R\&B light combinations (BP ranging from $10 \%$ to $30 \%$ ).

\section{Plant growth and yield as influenced by RP, BP, and GP}

Previous studies have indicated that different light wavelengths can regulate not only plant photosynthesis but also plant growth and development. Particularly, R wavelengths stimulate plant extension growth (i.e., stem elongation and leaf expansion) via phytochrome-mediated pathways, whereas B wavelengths inhibit plant extension growth via cryptochrome-mediated and phototropin-mediated pathways (Bugbee, 2016). In this study, the plant yield of all tested species decreased with increasing BP, except for red mustard, which showed a trend similar to that of plant height and leaf area (Figs. 4 and 5) and opposite that of comparative $\mathrm{P}_{\mathrm{n}}$ (Fig. 2). This indicated that plant biomass accumulation is predominantly related to plant extension growth (i.e., plant height, leaf area) rather than plant photosynthetic capacity. Plant extension growth and $\mathrm{P}_{\mathrm{n}}$ are two key elements determining plant photosynthetic capacity; the former determines the plant light interception capacity and the latter indicates the instantaneous gas exchange rate per unit of leaf area. Our results were consistent with those of Hernandez et al. (2016), who reported that plant height, leaf area, and shoot FW and DW of 'Cumlaude' cucumber decreased with increasing BP from $10 \%$ to $75 \%$, whereas $\mathrm{P}_{\mathrm{n}}$, stomatal conductance, and chlorophyll concentrations showed an opposite trend. Similarly, leaf length and width of 'Green Skirt' lettuce decreased with increasing BP from $0 \%$ to $30 \%$ (Kang et al., 2016).

Shade avoidance responses such as the promotion of hypocotyl elongation, stem elongation, and leaf expansion are evoked by $\mathrm{G}$ wavelengths in a range of plant species and have two categories: cryptochrome-dependent pathways and cryptochrome-independent pathways (Folta, 2004; Wang and Folta, 2013; Zhang et al., 2011). However, the inclusion of G wavelengths at high proportions reduces the photon flux of $\mathrm{R}$ and/or B wavelengths under constant $P P F D$, which may result in negative effects on plant growth (Folta and Maruhnich, 2007). For example, leaf area, leaf thickness, and plant yield of 'Waldmann's Green' lettuce increased under $24 \%$ GP $\left(\mathrm{R}_{61} \mathrm{~B}_{15}\right.$ $\mathrm{G}_{24}$ ) compared with plants grown under the $\mathrm{R} \& \mathrm{~B}$ light combination $\left(\mathrm{R}_{84} \mathrm{~B}_{16}\right)$, whereas treatment with $51 \%$ GP $\left(\mathrm{R}_{30} \mathrm{~B}_{19}\right.$ $\mathrm{G}_{51}$ ) showed no effects on leaf area or yield, and treatments with $86 \%$ GP $\left(\mathrm{R}_{4} \mathrm{~B}_{10} \mathrm{G}_{86}\right)$ decreased the leaf area and yield (Kim et al., 2004). In this study, due to the high GP ( $41 \%$ and $44 \%$ ), the inclusion of $\mathrm{G}$ wavelengths reduced the leaf area and subsequently reduced the shoot $\mathrm{FW}$ and DW.

A novel finding of this study is that the effects of the inclusion of $\mathrm{G}$ wavelengths on stem elongation differed under different RP and/or BP or R:B ratios. In particular, under low $\mathrm{BP}$ of $12 \%$, the inclusion of $\mathrm{G}$ wavelengths increased the plant height of green basil and green mustard; however, under high BP of $24 \%$, the inclusion of $\mathrm{G}$ wavelengths decreased plant height in most tested species (Fig. 4). It was postulated that under low $\mathrm{BP}$ of $12 \%$, which has a relatively low B photon flux and high R:B ratio (88:12 and 44:12), G wavelengths reverse the $\mathrm{B}$ wavelength inhibition responses and dominate in stem elongation, resulting in higher plant height. Under high BP of $24 \%$, a relatively high B photon flux and low R:B ratio (76:24 and 35:24) together may suppress stem elongation and override the weak control of expansion growth by $G$ wavelengths, resulting in shorter plant height. Wang and Folta (2013) also reported that the hypocotyl length of arabidopsis (Arabidopsis thaliana) increased with additional $\mathrm{G}$ wavelengths to a low $\mathrm{R}$ and B photon flux $\left(<1-10 \mu \mathrm{mol} \cdot \mathrm{m}^{-2} \cdot \mathrm{s}^{-1}\right)$ and showed no effects at a high $\mathrm{R}$ and $\mathrm{B}$ photon flux $\left(\geq 10 \mu \mathrm{mol} \cdot \mathrm{m}^{-2} \cdot \mathrm{s}^{-1}\right)$. This suggests that plant responses to $\mathrm{G}$ wavelengths not only depend on GP or G photon flux in total PPFD but also are influenced by the BP or $\mathrm{R}: \mathrm{B}$ ratio.

\section{Secondary metabolites accumulation as influenced by RP, BP, and GP}

Although both $\mathrm{R}$ and $\mathrm{B}$ wavelengths are involved in the synthesis of secondary metabolites, B wavelengths enriched the concentrations of phytochemicals compared with $\mathrm{R}$ wavelengths in most cases (Lobiuc et al., 2017; Qian et al., 2016). For example, the anthocyanin concentration in lettuce, sage, and kale increased under higher BP with constant $P P F D$, as did the phenolics concentration in purple basil (Hosseini et al., 2018; Li, 2010; Meng et al., 2004; Qian et al., 2016). Similarly, the antioxidant capacity of lettuce and kale both increased under enriched B wavelengths (Qian et al., 2016; Son and Oh, 2013). In this study, increases in BP enriched the concentration of anthocyanin in green kale, the concentration of phenolics in all tested species except green basil and red mustard, and the concentration of flavonoids in and antioxidant capacity of purple basil (Table 1). Induced synthesis of secondary metabolites by B wavelengths is supported by $\mathrm{Li}$ (2010) and Meng et al. (2004), who reported that the expression of key enzymes in the synthesis of polyphenols, such as phenylalanine ammonia lyase (PAL), chalcone synthase (CHS), and dihydroflavonol 4reductase (DFR), increased under B wavelengths. In contrast, increases in BP decreased the total amount of phytochemicals per plant, which was consistent with the trend of shoot FW (Fig. 5; Table 2). Therefore, two mechanisms of increased phytochemical concentrations under higher BP were postulated: 1) higher BP induced the expression of key enzymes in the phenylpropanoid pathway, such as PAL, CHS, and DFR, which induced the synthesis of anthocyanin, phenolics, and flavonoids (Li, 2010; Meng et al., 2004); and 2) reduced phytochemical concentrations under higher RP could be attributed to the dilution of phytochemicals at higher plant biomass. More research is need to identify the mechanism of B wavelengthenriched phytochemical concentrations.

Interactions between $\mathrm{G}$ and $\mathrm{R} \& \mathrm{~B}$ light combinations are difficult to predict but are known to be mediated by photosensory pathways because photoreceptors such as phytochromes, phototropins, and cryptochromes also absorb G wavelengths (Folta and Maruhnich, 2007; Wang and Folta, 2013; Zhang and Folta, 2012). Specifically, plant responses to $G$ wavelengths share a general tendency to counteract the B wavelength-induced anthocyanin accumulation in a range of plant species such as arabidopsis and lettuce (Talbott et al., 2006; Zhang et al., 2011; Zhang and Folta, 2012). Pennisi et al. (2019) reported that $G$ wavelengths $\left(R_{29} B_{31} G_{40}\right)$ significantly decreased the antioxidant capacity of and flavonoid concentration in basil compared with plants grown under $\mathrm{R} \& \mathrm{~B}$ light combinations $\left(\mathrm{R}_{62} \mathrm{~B}_{30}\right)$. However, the inclusion of $\mathrm{G}$ wavelengths showed both positive and negative effects on phytochemical accumulation in this study (Tables 1 and 2). With similar BP, the decreased phytochemical concentration with the 
inclusion of $\mathrm{G}$ wavelengths was postulated to be caused by the $\mathrm{G}$ wavelength reversal of $B$ wavelength-induced phytochemical synthesis (Zhang and Folta, 2012). However, the concentration and total amount of anthocyanin in green kale both increased with the inclusion of $\mathrm{G}$ wavelengths under $12 \% \mathrm{BP}$, suggesting a novel pathway for anthocyanin synthesis induced by $G$ wavelengths. One hypothesis is that under low BP of $12 \%$, the inclusion of $\mathrm{G}$ wavelengths may increase the high-energy wavelengths intercepted by green kale compared with R\&B light combinations with similar BP, which induced anthocyanin synthesis as a stress response.

\section{Conclusion}

The results of this study suggest that adjusting the suitable spectrum of light wavelengths may provide important tools for regulating plant photosynthesis, morphology, biomass accumulation, and phytochemical synthesis. Increases in BP improved plant photosynthesis and phytochemical concentrations but suppressed plant expansion growth, yield, and the total amount of phytochemicals per plant. Effects of the inclusion of $G$ wavelengths on stem elongation differed under different RP and/or BP and R:B ratios, and relatively high GP negatively influenced plant photosynthesis, chlorophyll content, leaf area, and yield. The inclusion of $G$ wavelengths showed both positive and negative effects on phytochemical accumulation in this study. More research is required to clarify the effects of $G$ wavelengths on secondary metabolites synthesis.

\section{Literature Cited}

Amaki, W., N. Yamazaki, M. Ichimura, and H. Watanabe. 2011. Effects of light quality on the growth and essential oil content in sweet basil. Acta Hort. 907:91-94.

Arnao, M.B., A. Cano, and M. Acosta. 2001. The hydrophilic and lipophilic contribution to total antioxidant activity. Food Chem. 73(2):239-244.

Banerjee, R., E. Schleicher, S. Meier, R.M. Viana, R. Pokorny, M. Ahmad, R. Bittl, and A. Batschauer. 2007. The signaling state of arabidopsis cryptochrome 2 contains flavin semiquinone. J. Biol. Chem. 282(20):14916-14922.

Bondada, B.R. and J.P. Syvertsen. 2003. Leaf chlorophyll, net gas exchange and chloroplast ultrastructure in citrus leaves of different nitrogen status. Tree Physiol. 23(8):553-559.

Bouly, J.P., E. Schleicher, M. Dionisio-Sese, F. Vandenbussche, D. Van Der Straeten, N. Bakrim, S. Meier, A. Batschauer, P. Galland, and R. Bittl. 2007. Cryptochrome blue light photoreceptors are activated through interconversion of flavin redox states. J. Biol. Chem. 282(13):9383-9391.

Bugbee, B. 2016. Toward an optimal spectral quality for plant growth and development: The importance of radiation capture. Acta Hort. 1134:1-12.

Connor, A.M., J.J. Luby, and C.B. Tong. 2002. Variability in antioxidant activity in blueberry and correlations among different antioxidant activity assays. J. Amer. Soc. Hort. Sci. 127:238-244.

Craver, J.K., K.S. Nemali, and R.G. Lopez. 2020. Acclimation of growth and photosynthesis in petunia seedlings exposed to highintensity blue radiation. J. Amer. Soc. Hort. Sci. 145:152-161.

Darko, E., P. Heydarizadeh, B. Schoefs, and M.R. Sabzalian. 2014. Photosynthesis under artificial light: The shift in primary and secondary metabolism. Phil. Trans. R. Soc. B Biol. Sci. 369(1640):20130243. Despommier, D. 2013. Farming up the city: The rise of urban vertical farms. Trends Biotechnol. 31(7):388-389.

Dou, H., G. Niu, M. Gu, and J.G. Masabni. 2017. Effects of light quality on growth and phytonutrient accumulation of herbs under controlled environments. Horticulturae 3(2):36.
Dou, H., G. Niu, M. Gu, and J.G. Masabni. 2018. Responses of sweet basil to different daily light integrals in photosynthesis, morphology, yield, and nutritional quality. HortScience 53:496-503.

Dou, H., G. Niu, and M. Gu. 2019a. Photosynthesis, morphology, yield, and phytochemical accumulation in basil plants influenced by substituting green light for partial red and/or blue light. HortScience 54:1769-1776.

Dou, H., G. Niu, and M. Gu. 2019b. Pre-harvest UV-B radiation and photosynthetic photon flux density interactively affect plant photosynthesis, growth, and secondary metabolites accumulation in basil (Ocimum basilicum) plants. Agronomy 9:434, doi: 10.3390/ agronomy 9080434.

Fan, X., J. Zang, Z. Xu, S. Guo, X. Jiao, X. Liu, and Y. Gao. 2013. Effects of different light quality on growth, chlorophyll concentration and chlorophyll biosynthesis precursors of non-heading chinese cabbage (Brassica campestris L.). Acta Physiol. Plant. 35(9):2721-2726.

Folta, K.M. 2004. Green light stimulates early stem elongation, antagonizing green light-mediated growth inhibition. Plant Physiol. 135(3):1407-1416.

Folta, K.M. and S.A. Maruhnich. 2007. Green light: A signal to slow down or stop. J. Expt. Bot. 58(12):3099-3111.

Hernandez, R., T. Eguchi, and C. Kubota. 2016. Growth and morphology of vegetable seedlings under different blue and red photon flux ratios using green light-emitting diodes as sole-source lighting. Acta Hort. 1134:195-200.

Hogewoning, S.W., G. Trouwborst, H. Maljaars, H. Poorter, W. van Ieperen, and J. Harbinson. 2010. Blue light dose-responses of leaf photosynthesis, morphology, and chemical composition of Cucumis sativus grown under different combinations of red and blue light. J. Expt. Bot. 61(11):3107-3117.

Hosseini, A., M. Zare Mehrjerdi, and S. Aliniaeifard. 2018. Alteration of bioactive compounds in two varieties of basil (Ocimum basilicum) grown under different light spectra. J. Essent. Oil-Bear. Plants 21(4):913-923.

Johkan, M., K. Shoji, F. Goto, S.N. Hashida, and T. Yoshihara. 2010. Blue light-emitting diode light irradiation of seedlings improves seedling quality and growth after transplanting in red leaf lettuce. HortScience 45:1809-1814.

Kang, W.H., J.S. Park, K.S. Park, and J.E. Son. 2016. Leaf photosynthetic rate, growth, and morphology of lettuce under different fractions of red, blue, and green light from light-emitting diodes (LEDs). Hort. Environ. Biotechnol. 57(6):573-579.

Keservani, R.K., R.K. Kesharwani, N. Vyas, S. Jain, R. Raghuvanshi, and A.K. Sharma. 2010. Nutraceutical and functional food as future food: A review. Pharm. Lett. 2(1):106-116.

Kim, H.H., G.D. Goins, R.M. Wheeler, and J.C. Sager. 2004. Greenlight supplementation for enhanced lettuce growth under red- and blue-light-emitting diodes. HortScience 39:1617-1622.

Kinoshita, T., M. Doi, N. Suetsugu, T. Kagawa, M. Wada, and K. Shimazaki. 2001. Phot1 and phot2 mediate blue light regulation of stomatal opening. Nature 414:656-660.

Klem, K., A. Gargallo-Garriga, W. Rattanapichai, M. Oravec, P. Holub, B. Vesela, J. Sardans, J. Penuelas, and O. Urban. 2019. Distinct morphological, physiological, and biochemical responses to light quality in barley leaves and roots. Frontiers Plant Sci. 10:1026.

Kopsell, D.A., C.E. Sams, T.C. Barickman, and R.C. Morrow. 2014. Sprouting broccoli accumulate higher concentrations of nutritionally important metabolites under narrow-band light-emitting diode lighting. J. Amer. Soc. Hort. Sci. 139:469-477.

Kozai, T., G. Niu, and M. Takagaki (eds.). 2015. Plant factory: An indoor vertical farming system for efficient quality food production. Academic Press, San Diego, CA.

Li, Q. 2010. Effects of light quality on growth and phytochemical accumulation of lettuce and Salvia miltiorrhiza bunge. PhD Diss., Northwest A\&F Univ., Shanxi, China. 
Li, Q. and C. Kubota. 2009. Effects of supplemental light quality on growth and phytochemicals of baby leaf lettuce. Environ. Exp. Bot. 67(1):59-64.

Lobiuc, A., V. Vasilache, M. Oroian, T. Stoleru, M. Burducea, O. Pintilie, and M.M. Zamfirache. 2017. Blue and red LED illumination improves growth and bioactive compounds contents in acyanic and cyanic Ocimum basilicum L. microgreens. Molecules 22(12):2111.

Logan, B.A., W.C. Stafstrom, M.J. Walsh, J.S. Reblin, and K.S. Gould. 2015. Examining the photoprotection hypothesis for adaxial foliar anthocyanin accumulation by revisiting comparisons of green- and red-leafed varieties of coleus (Solenostemon scutellarioides). Photosynth. Res. 124(3):267-274.

Makri, O. and S. Kintzios. 2008. Ocimum sp. (basil): Botany, cultivation, pharmaceutical properties, and biotechnology. J. Herbs Spices Med. Plants 13(3):123-150.

McCree, K.J. 1972. The action spectrum, absorptance and quantum yield of photosynthesis in crop plants. Agr. Meteorol. 9:191-216.

Meng, Q., N. Kelly, and E.S. Runkle. 2019. Substituting green or farred radiation for blue radiation induces shade avoidance and promotes growth in lettuce and kale. Environ. Exp. Bot. 162:383-391.

Meng, X., T. Xing, and X. Wang. 2004. The role of light in the regulation of anthocyanin accumulation in Gerbera hybrida. Plant Growth Regulat. 44(3):243-250.

Mitchell, C.A., M.P. Dzakovich, C. Gomez, R. Lopez, J.F. Burr, R. Hernandez, C. Kubota, C.J. Currey, Q. Meng, and E.S. Runkle. 2015. Light-emitting diodes in horticulture. Hort. Rev. 43:1-87.

Nishioka, N., T. Nishimura, K. Ohyama, M. Sumino, S. Malayeri, E. Goto, N. Inagaki, and T. Morota. 2008. Light quality affected growth and contents of essential oil components of japanese mint plants. Acta Hort. 797:431-436.

Ohashi-Kaneko, K., M. Takase, N. Kon, K. Fujiwara, and K. Kurata. 2007. Effect of light quality on growth and vegetable quality in leaf lettuce, spinach and komatsuna. Environ. Control Biol. 45(3):189198.

Ouzounis, T., E. Rosenqvist, and C.O. Ottosen. 2015. Spectral effects of artificial light on plant physiology and secondary metabolism: A review. HortScience 50:1128-1135.

Pennisi, G., S. Blasioli, A. Cellini, L. Maia, A. Crepaldi, I. Braschi, F. Spinelli, S. Nicola, J.A. Fernández, and C. Stanghellini. 2019. Unravelling the role of red:blue LED lights on resource use efficiency and nutritional properties of indoor grown sweet basil. Frontiers Plant Sci. 10:305.

Piovene, C., F. Orsini, S. Bosi, R. Sanoubar, V. Bregola, G. Dinelli, and G. Gianquinto. 2015. Optimal red:blue ratio in LED lighting for nutraceutical indoor horticulture. Scientia Hort. 193:202-208.

Qian, H., T. Liu, M. Deng, H. Miao, C. Cai, W. Shen, and Q. Wang. 2016. Effects of light quality on main health-promoting compounds and antioxidant capacity of chinese kale sprouts. Food Chem. 196:1232-1238.
Rouphael, Y., M.C. Kyriacou, S.A. Petropoulos, S. De Pascale, and G. Colla. 2018. Improving vegetable quality in controlled environment. Scientia Hort. 234:275-289.

Sager, J., W. Smith, J. Edwards, and K. Cyr. 1988. Photosynthetic efficiency and phytochrome photoequilibria determination using spectral data. Trans. Amer. Soc. Agr. Eng. 31(6):1882-1889.

Shiga, T., K. Shoji, H. Shimada, S.N. Hashida, F. Goto, and T. Yoshihara. 2009. Effect of light quality on rosmarinic acid content and antioxidant activity of sweet basil, Ocimum basilicum L. Plant Biotechnol. 26(2):255-259.

Shoji, K., E. Goto, S. Hashida, F. Goto, and T. Yoshihara. 2011. Effect of light quality on the polyphenol content and antioxidant activity of sweet basil (Ocimum basilicum L.). Acta Hort. 907:95-99.

Snowden, M.C., K.R. Cope, and B. Bugbee. 2016. Sensitivity of seven diverse species to blue and green light: Interactions with photon flux. PLoS One 11(10):e0163121.

Son, K.H. and M.M. Oh. 2013. Leaf shape, growth, and antioxidant phenolic compounds of two lettuce cultivars grown under various combinations of blue and red light-emitting diodes. HortScience 48:988-995.

Stutte, G.W. 2009. Light-emitting diodes for manipulating the phytochrome apparatus. HortScience 44:231-234.

Talbott, L.D., J.W. Hammad, L.C. Harn, V.H. Nguyen, J. Patel, and E. Zeiger. 2006. Reversal by green light of blue light-stimulated stomatal opening in intact, attached leaves of arabidopsis operates only in the potassium-dependent, morning phase of movement. Plant Cell Physiol. 47(3):332-339.

Terashima, I., T. Fujita, T. Inoue, W.S. Chow, and R. Oguchi. 2009. Green light drives leaf photosynthesis more efficiently than red light in strong white light: Revisiting the enigmatic question of why leaves are green. Plant Cell Physiol. 50(4):684-697.

Tornaghi, C. 2017. Urban agriculture in the food-disabling city: (Re)defining urban food justice, reimagining a politics of empowerment. Antipode 49(3):781-801.

Wang, Y. and K.M. Folta. 2013. Contributions of green light to plant growth and development. Amer. J. Bot. 100(1):70-78.

Wollaeger, H.M. and E.S. Runkle. 2014. Growth of impatiens, petunia, salvia, and tomato seedlings under blue, green, and red light-emitting diodes. HortScience 49:734-740.

Xu, C.P. and B.Q. Mou. 2016. Responses of spinach to salinity and nutrient deficiency in growth, physiology, and nutritional value. J. Amer. Soc. Hort. Sci. 141:12-21.

Zeiger, E., L.D. Talbott, S. Frechilla, A. Srivastava, and J. Zhu. 2002. The guard cell chloroplast: A perspective for the twenty-first century. New Phytol. 153:415-424.

Zhang, T. and K.M. Folta. 2012. Green light signaling and adaptive response. Plant Signal. Behav. 7(1):75-78.

Zhang, T., S.A. Maruhnich, and K.M. Folta. 2011. Green light induces shade avoidance symptoms. Plant Physiol. 157(3):1528-1536. 